\title{
The Land Use Model Intercomparison Project (LUMIP) contribution to CMIP6: rationale and experimental design
}

\author{
David M. Lawrence ${ }^{1}$, George C. Hurtt ${ }^{2}$, Almut Arneth ${ }^{3}$, Victor Brovkin ${ }^{4}$, Kate V. Calvin ${ }^{5}$, Andrew D. Jones ${ }^{6}$, \\ Chris D. Jones $^{7}$, Peter J. Lawrence ${ }^{1}$, Nathalie de Noblet-Ducoudré ${ }^{8}$, Julia Pongratz ${ }^{4}$, Sonia I. Seneviratne ${ }^{9}$, and \\ Elena Shevliakova $^{10}$ \\ ${ }^{1}$ National Center for Atmospheric Research, Boulder, CO, USA \\ ${ }^{2}$ University of Maryland, College Park, MD, USA \\ ${ }^{3}$ Karlsruhe Institute of Technology, Garmisch-Partenkirchen, Germany \\ ${ }^{4}$ Max Planck Institute for Meteorology, Hamburg, Germany \\ ${ }^{5}$ Joint Global Change Research Institute, College Park, MD, USA \\ ${ }^{6}$ Lawrence Berkeley National Laboratory, Berkeley, CA, USA \\ ${ }^{7}$ Met Office Hadley Centre, Exeter, UK \\ ${ }^{8}$ Laboratoire des Sciences du Climat et de l'Environnement, Gif-sur-Yvette, France \\ ${ }^{9}$ Institute for Atmospheric and Climate Science, ETH Zurich, Zurich, Switzerland \\ ${ }^{10}$ NOAA/GFDL and Princeton University, Princeton, NJ, USA
}

Correspondence to: David M. Lawrence (dlawren@ucar.edu)

Received: 4 April 2016 - Published in Geosci. Model Dev. Discuss.: 12 April 2016

Revised: 10 August 2016 - Accepted: 11 August 2016 - Published: 2 September 2016

\begin{abstract}
Human land-use activities have resulted in large changes to the Earth's surface, with resulting implications for climate. In the future, land-use activities are likely to expand and intensify further to meet growing demands for food, fiber, and energy. The Land Use Model Intercomparison Project (LUMIP) aims to further advance understanding of the impacts of land-use and land-cover change (LULCC) on climate, specifically addressing the following questions. (1) What are the effects of LULCC on climate and biogeochemical cycling (past-future)? (2) What are the impacts of land management on surface fluxes of carbon, water, and energy, and are there regional land-management strategies with the promise to help mitigate climate change? In addressing these questions, LUMIP will also address a range of more detailed science questions to get at process-level attribution, uncertainty, data requirements, and other related issues in more depth and sophistication than possible in a multi-model context to date. There will be particular focus on the separation and quantification of the effects on climate from LULCC relative to all forcings, separation of biogeochemical from biogeophysical effects of land use, the unique impacts of land-cover change vs. land-management change, modulation
\end{abstract}

of land-use impact on climate by land-atmosphere coupling strength, and the extent to which impacts of enhanced $\mathrm{CO}_{2}$ concentrations on plant photosynthesis are modulated by past and future land use.

LUMIP involves three major sets of science activities: (1) development of an updated and expanded historical and future land-use data set, (2) an experimental protocol for specific LUMIP experiments for CMIP6, and (3) definition of metrics and diagnostic protocols that quantify model performance, and related sensitivities, with respect to LULCC. In this paper, we describe LUMIP activity (2), i.e., the LUMIP simulations that will formally be part of CMIP6. These experiments are explicitly designed to be complementary to simulations requested in the CMIP6 DECK and historical simulations and other CMIP6 MIPs including ScenarioMIP, C4MIP, LS3MIP, and DAMIP. LUMIP includes a twophase experimental design. Phase one features idealized coupled and land-only model simulations designed to advance process-level understanding of LULCC impacts on climate, as well as to quantify model sensitivity to potential landcover and land-use change. Phase two experiments focus on quantification of the historic impact of land use and the po- 
tential for future land management decisions to aid in mitigation of climate change. This paper documents these simulations in detail, explains their rationale, outlines plans for analysis, and describes a new subgrid land-use tile data request for selected variables (reporting model output data separately for primary and secondary land, crops, pasture, and urban land-use types). It is essential that modeling groups participating in LUMIP adhere to the experimental design as closely as possible and clearly report how the model experiments were executed.

\section{Introduction}

Historic land-cover and land-use change has dramatically altered the character of the Earth's surface, directly impacting climate and perturbing natural biogeochemical cycles. Landuse activities are expected to expand and/or intensify in the future to meet increasing human demands for food, fiber, and energy. From a broad perspective, the biogeophysical impacts of land-use and land-cover change (LULCC) on climate are relatively well understood, with observational and modeling studies tending to agree that deforestation has led and will lead to cooling in high latitudes and warming in the tropics, with more uncertain changes in the mid-latitudes (e.g., Bonan, 2008; Davin and de Noblet-Ducoudré, 2010; Lee et al., 2011; Li et al., 2016; Pielke et al., 2011; Swann et al., 2012). The impact of land-cover change on, for example, global mean surface air temperature, has been and is projected to continue to be relatively small (Brovkin et al., 2013; Lawrence et al., 2012), but, regionally, climate change due to deforestation can be as large as or larger than that resulting from increases in greenhouse gas emissions (de Noblet-Ducoudré et al., 2012). Nonetheless, substantial disagreement exists across models in terms of their simulated regional climate response to LULCC (Kumar et al., 2013; Pitman et al., 2009), and some observed effects do not appear to be captured by models (Lejeune et al., 2016), contributing to a lack of confidence in model projections of regional climate change. Variation among future scenarios of landuse change, which could depart significantly from historical trends due to large-scale adoption of either afforestation or biofuel policies, introduces another source of uncertainty that has not been examined in a systematic fashion (Jones et al., 2013b).

The biogeochemical impact of LULCC relates to emissions of greenhouse gases (GHGs) such as $\mathrm{CO}_{2}, \mathrm{CH}_{4}$, and $\mathrm{N}_{2} \mathrm{O}$ in response to LULCC (e.g., Canadell et al., 2007; Houghton, 2003; Pongratz et al., 2009; Shevliakova et al., 2009). Models estimate that the net LULCC carbon flux the $\mathrm{CO}_{2}$ exchange between vegetation and atmosphere due to LULCC such as emissions due to forest clearing and carbon uptake in regrowth of harvested forest - has accounted for $\sim 25 \%$ of the historic increase in atmospheric carbon diox- ide concentration (Ciais et al., 2014), but the LULCC flux remains one of the most uncertain terms in the global carbon budget (Houghton et al., 2012). As on the biogeophysical side, models show a wide range of estimates for historic and future emissions due to LULCC (Arora and Boer, 2010; Boysen et al., 2014; Brovkin et al., 2013). When emissions of all GHG species due to LULCC are considered, the forcing due to LULCC accounts for $\sim 45 \%$ of the total historic (1850 to 2010) changes in radiative forcing (Ward et al., 2014).

At the same time, there is growing awareness that the details of land use matter and that land management or land-use intensification can have as much of an impact on climate as land-cover change itself. Luyssaert et al. (2014) emphasize that while humans have instigated land-cover change over about $18-29 \%$ of the ice-free land surface, a much larger fraction of the planet $(42-58 \%)$ has not experienced landcover change per se, but is nonetheless managed, sometimes intensively, to satisfy human demands for food and fiber. Furthermore, the temperature impacts, assessed through remote sensing and paired tower sites, are roughly equivalent for land-management change and land-cover change. Other examples of research indicating the importance of specific aspects of land management are numerous. For example, irrigation, which has increased substantially over the 20th century (Jensen et al., 1990), can directly impact local and regional climate (Boucher et al., 2004; Sacks et al., 2009; Wei et al., 2013). In some regions, cooling trends associated with irrigation area expansion have likely offset warming due to greenhouse gas increases (Lobell et al., 2008a). Explicit representation of the crop life cycle also appears to be important: Levis et al. (2012) showed that including an interactive crop model in a global climate model (GCM) can improve the seasonality of surface turbulent fluxes and net ecosystem exchange and thereby directly impact weather and climate and the carbon cycle. In another study, Pugh et al. (2015) found that accounting for harvest, grazing, and tillage resulted in cumulative post-1850 land-use-related carbon loss that was $70 \%$ greater than in simulations ignoring these processes. There is a hypothesis that increasing crop production over the 20th century could account for $\sim 25 \%$ of the observed increase in the amplitude of the $\mathrm{CO}_{2}$ annual cycle (Gray et al., 2014; Zeng et al., 2014). Furthermore, agricultural practices can mitigate heat extremes through the cooling effects of irrigation (Lobell et al., 2008b), due to enhanced evapotranspiration associated with cropland intensification (Mueller et al., 2016), or by increasing surface albedo by transitioning to notill farming (Davin et al., 2014). Forest management and the harvesting of trees for wood products or fuel is also important and has substantial carbon cycle consequences (Hurtt et al., 2011), with the carbon flux due to wood harvest amounting to an equivalent of up to $15 \%$ of the forest net primary production in strongly managed regions such as Europe (Luyssaert et al., 2010). Awareness that land management can impact climate has led to open questions about whether or not there is potential for implementation of specific land management 
as a tool for local or global climate mitigation (e.g., Canadell and Raupach, 2008; Marland et al., 2003).

Due to the predicted increases in global population and affluence as well as the increasing importance of bioenergy, demand for food and fiber is likely to surge during the coming decades. Expansion of active management into relatively untouched regions could satisfy a portion of the growing demand for food and fiber, but intensification is likely to play a stronger role in strategies for global sustainability (Foley et al., 2011; Reid et al., 2010). Therefore, we can anticipate a growing contribution from land-management change to the overall impacts of LULCC on the climate system. The requirement of negative emissions to achieve low radiative forcing targets highlights the need for more comprehensive understanding of the impacts (e.g., on land use, water, nutrients, and albedo) and sustainability of carbon removal strategies such as bioenergy carbon capture and storage (BECCS, Smith et al., 2016).

Clearly, the impacts of land cover and land use on climate are myriad and diverse and, while uncertain, are sufficiently large and complex to warrant an expanded activity focused on land use within CMIP6. The Land Use Model Intercomparison Project (Lawrence et al., 2016, https://cmip. ucar.edu/lumip) addresses this topic in the context of CMIP6 (Eyring et al., 2016). The goal of LUMIP is to enable, coordinate, and ultimately address the most important science questions related to the effects of land use on climate. LUMIP scientific priorities and model experiments have been developed in consultation with several existing model intercomparison activities and research programs that focus on the role of land use in climate, including the Land-Use and Climate, IDentification of robust impacts project (LUCID, de Noblet-Ducoudré et al., 2012; Pitman et al., 2009), the Land-use change: assessing the net climate forcing, and options for climate change mitigation and adaptation project (LUC4C, http://luc4c.eu/), the trends in net land carbon exchange project (TRENDY, http://dgvm.ceh.ac.uk/node/9), and the Global Soil Wetness Project (GSWP3). In addition, the LUMIP experimental design is complementary with and in some cases requires simulations from several other CMIP6 MIPs, including ScenarioMIP (O’Neill et al., 2016), C4MIP (Jones et al., 2016), LS3MIP (van den Hurk et al., 2016), DAMIP (Gillett et al., 2016), and RFMIP (Pincus et al., 2016). In all cases, the LUMIP experiments are complementary and not duplicative with experiments requested in these other MIPs. We will reference these cross-MIP interactions throughout this paper, where applicable.

\subsection{LUMIP activities}

The main science questions that will be addressed by LUMIP in the context of CMIP6 are the following.

- What are the global and regional effects of land-use and land-cover change on climate and biogeochemical cycling (past-future)?
- What are the impacts of land management on surface fluxes of carbon, water, and energy?

- Are there regional land-use or land-management strategies with the promise to help mitigate climate change?

In addressing these questions, LUMIP will also address a range of more detailed science questions to get at processlevel attribution, uncertainty, data requirements, and other related issues in more depth and sophistication than has been possible in a multi-model context to date. There will be particular focus on (1) the separation and quantification of the effects on climate from LULCC relative to all forcings, (2) separation of biogeochemical from biogeophysical effects of land use, (3) the unique impacts of land-cover change vs. land-use change, (4) modulation of land-use impact on climate by land-atmosphere coupling strength, and (5) the extent to which the direct effects of higher $\mathrm{CO}_{2}$ concentrations on increases in global plant productivity are modulated by past and future land use.

Three major sets of science activities are planned within LUMIP. First, a new set of global gridded land-use forcing data sets has been developed to link historical land-use data and future projections in a standard format required by climate models (Fig. 1). This new generation of "land-use harmonization" (LUH2) builds upon past work from CMIP5 (Hurtt et al., 2011), and includes updated inputs, higher spatial resolution, more detailed land-use transitions, and the addition of important agricultural management layers. The new data set includes annual land-use states, transitions, and management layers for the years 850 to 2100 at $0.25^{\circ}$ spatial resolution. Note that land-cover data and forest/non-forest data, as well as land-use transitions, will be provided in the new data set in order to help minimize misinterpretation of the land-use data set that occurred in CMIP5, where, for example, the strong afforestation in RCP4.5 was not captured in Community Earth System Model (CESM) simulations because of differing assumptions embedded within the CESM land-use translator (a software package that translates the LUH data into CESM land-cover data sets) and the LUH data set (Di Vittorio et al., 2014). Several harmonized future land-use trajectories will be processed for the period 2016-2100 in support of the ScenarioMIP Shared Socioeconomic Pathway scenarios (see Sect. 2.3.2). Cropland is disaggregated into five crop functional types based on input data from FAO and Monfreda et al. (2008). Crop rotations are also included. Grazing lands are disaggregated into managed pastures and rangelands based on input data from the updated HYDE3.2 data set (updated from HYDE3.1, Klein Goldewijk et al., 2011), which also provides inputs for gridded cropland, urban, and irrigated areas. The modeling process includes new underlying maps of potential biomass density and biomass recovery rate, which are used to disaggregate both primary and secondary natural vegetation into forested and non-forested land. It also includes a new representation of shifting cultivation rates and 

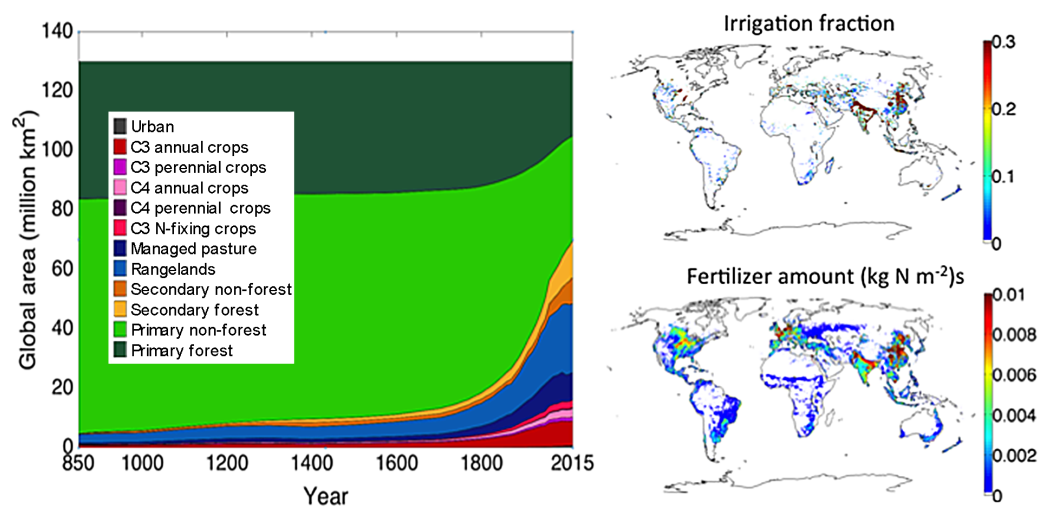

Figure 1. Time series of global land area occupied by each LUH2 land-use state from 850 to 2015 (left). Note that extensions to 2100 for all of the ScenarioMIP SSPs will also be provided. Fraction of each $0.25^{\circ}$ grid cell that is irrigated in year 2015 (top right). Fertilizer applied in year 2015 (bottom right).

extent, constrains forest loss between the years 2000 and 2012 with Landsat-based forest loss data from Hansen et al. (2013), and uses a new historical wood harvest reconstruction based on updated FAO data, new HYDE population data, and other sources. The LUH2 data set will include several new agricultural management layers such as gridded nitrogen fertilizer usage based on Zhang et al. (2015), gridded irrigated areas (based on HYDE3.2), and gridded areas flooded for rice (also based on HYDE3.2), as well as the disaggregation of wood harvest into fuel wood and industrial roundwood (i.e., timber that is cut for uses other than for fuel). Future scenarios (years 2016-2100) will also include biofuel management layers. To help address the issue of sensitivity to uncertainty in historical land-use forcing, two alternative historical land-use reconstructions have also been developed. These alternatives are based on same data sources, use the same algorithms, and are provided in the same format as the reference LUH2 product, but span a range of uncertainty in the key historical input data sets for agriculture and wood harvest. Specifically, the "high" reconstruction assumes high historical estimates for crop and pasture and wood harvest, and the "low" reference assumes low estimates for each of these terms, relative to the reference.

The LUH2 data set is available through the LUMIP website (https://cmip.ucar.edu/lumip) and will be described in a separate publication in this CMIP6 Special Issue. Guidance on use of the data will be provided in the LUH2 data set paper and through the LUMIP website.

Second, an efficient model experiment design, including both idealized and scenario-based cases, is defined that will enable isolation and quantification of land-use effects on climate and the carbon cycle (see Sect. 2). The LUMIP experimental protocol enables integrated analysis of coupled and land-only (forced with observed meteorology) models that will support understanding and assessment of the forced response and climate feedbacks associated with land use and the relationship of these responses with land and atmosphere model biases.

Third, a set of metrics and diagnostic protocols will be developed to quantify model performance, and related sensitivities, with respect to land use (see Sect. 3). De NobletDucoudré et al. (2012) identified the lack of consistent evaluation of a land model's ability to represent a response to a perturbation such as land-use change as a key contributor to the large spread in simulated land-cover change responses seen in LUCID. As part of this activity, benchmarking data products will be identified to help constrain models. Where applicable, these metrics will be incorporated into land model metrics packages such as the International Land Model Benchmarking (ILAMB, http://www.ilamb.org/) system.

New output data standardization will also enrich and expand analysis of model experiment results. Particular emphasis within LUMIP is on archival of subgrid land information in CMIP6 experiments (including LUMIP experiments and other relevant experiments from ScenarioMIP, C4MIP, and the CMIP historical simulation). In most land models, physical, ecological, and biogeochemical land state and surface flux variables are calculated separately for several different land surface type or land management "tiles" (e.g., natural and secondary vegetation, crops, pasture, urban, lake, glacier). Frequently, including in the CMIP5 archive, tilespecific quantities are averaged and only grid-cell mean values are reported. Consequently, a large amount of valuable information is lost with respect to how each land-use type responds to and interacts with climate change and direct anthropogenic modifications of the land surface. LUMIP has developed a protocol and associated data request for CMIP6 for selected key variables on separate land-use tiles within each grid cell (primary and secondary land, crops, pastureland, urban; see Sect. 4). 


\subsection{Relevance of LUMIP to CMIP6 questions and WCRP Grand Challenges}

Land-use change is an essential forcing of the Earth system, and as such LUMIP is directly relevant and necessary for CMIP6 Question (1) (Eyring et al., 2016): "How does the Earth System respond to forcing?". LUMIP will also play a strong role in addressing the WCRP Grand Challenges (GC), particularly with respect to GC7 "determining how biogeochemical cycles and feedbacks control greenhouse gas concentrations and climate change", GC3 "understanding the factors that control water availability over land", and GC4 "assessing climate extremes, what controls them, how they have changed in the past and how they might change in the future". Due to the broad range of effects of land-use change and the major activities proposed, LUMIP is also of crosscutting relevance to CMIP6 science questions (2) "What are the origins and consequences of systematic model biases?" and (3) "How can we assess future climate change given climate variability, climate predictability, and uncertainties in scenarios?".

\subsection{Definitions of land cover, land use, and land management}

Within LUMIP, we rely on prior definitions of land cover, land use, and land management (Lambin et al., 2006). Land cover refers to "the attributes of the Earth's land surface and immediate subsurface, including biota, soil, topography, surface and groundwater, and human (mainly built-up) structures", and is represented in land models by categories like forest, grassland, cropland, or urban areas. Land use is the "purpose for which humans exploit the land cover"; e.g., a grassland may be left in its natural state, mowed, or utilized as rangeland for livestock. Land management refers to ways in which humans treat vegetation, soil, and water, and is captured in land models by processes such as irrigation, use of fertilizers and pesticides, crop species selection, or methods of wood harvesting (selective logging vs. clear cutting). Thus, within the same land-cover category, several land uses can occur, and within the same land-use category, management practices can differ. Land-cover change usually goes hand in hand with land-use change, but the opposite is not true. Land-cover change can also be driven by natural processes such as a change in the biogeographic vegetation distribution due to climate shifts or natural disturbance (DaviesBarnard et al., 2015; Schneck et al., 2013). For the purposes of LUMIP, the term "LULCC" includes anthropogenically driven land-cover change only.

\section{Experimental design and description}

In this section, we begin with a discussion and recommendations on the specification of land use in CMIP6 Diagnostic, Evaluation and Characterization of Klima (DECK) and his- torical experiments and other MIP experiments (Sect. 2.1). Also in this section, we outline the full set of requested LUMIP experiments (Sects. 2.2 and 2.3). LUMIP includes a two-phase, tiered, model experiment plan. Phase one features a coupled model simulation with an idealized deforestation scenario that is designed to advance process-level understanding and to quantify model sensitivity to land-cover change impacts on climate and biogeochemical stocks and fluxes. Phase one also includes a factorial set of land-only model simulations that allow assessment of the forced response of land-atmosphere fluxes to land-cover change as well as examination of the impacts of various land-use and land-management practices. Phase two experiments will focus on the quantification of the historic impact of land use and the potential for future land-management decisions to aid in the mitigation of climate change. A forum for discussion of the experiments and for distribution of minor updates to or clarifications of the experimental design will be hosted at the LUMIP website (https://cmip.ucar.edu/lumip).

Details of the model experiments are described below. The full set of LUMIP experiments includes

- Tier 1 (high priority): 500 years GCM/ESM; $\sim 650$ years land-only; and

- Tier 2 (medium priority): 500 years GCM/ESM; up to 1500 to 3000 years land-only.

Note that these totals only represent the LUMIP-sponsored simulations. LUMIP analysis requires control simulations from other MIPs, e.g., a pre-industrial control DECK simulation or a CMIP6 historical simulation. We note the required "parent" simulation and responsible MIP, where applicable.

In Sects. 2.2 and 2.3, we describe each experiment in detail. Also included is the scientific rationale for the particular experiment or set of experiments. The heading for each experiment includes several relevant pieces of information according to the following format - Short description (CMIP6 experiment ID, model configuration, Tier $X$, \# years) - where the model configuration is either land-only (offline land simulations forced with observed meteorology), GCM (fully coupled simulation, concentration-driven), or ESM (fully coupled simulation, emissions-driven).

\subsection{Land-use treatment in the CMIP6 DECK, historical experiments, and other MIP experiments}

There exists a large diversity in representation of LULCC among different land models, and therefore it is typically non-trivial to define what is meant by the terms "land use" and, in particular, the term "constant land use". Several CMIP6 simulations both within LUMIP and in other CMIP6 MIPs require land use to be held constant in time, including (1) DECK experiments including $\mathrm{CO}_{2}$-concentration and $\mathrm{CO}_{2}$-emission driven pre-industrial control simulations ( $\mathrm{pi}$ Control), abrupt quadrupling of $\mathrm{CO}_{2}($ abrupt $-4 \times \mathrm{CO} 2)$ and 
$1 \%$ year $^{-1} \mathrm{CO}_{2}$ increase (1pctCO2) simulations, (2) LUMIP no land-use change simulations (Sect. 2.3.1), (3) C4MIP idealized simulations including biogeochemically coupled $1 \%$ year ${ }^{-1} \mathrm{CO}_{2}$ increase (1pctCO2-bgc) and other C4MIP Tier 2 idealized simulations, and (4) ScenarioMIP extension simulations for the period 2100-2300 (ssp126-ext, ssp585ext), for which land-use data will not be provided.

LUMIP provides the following recommendations to clarify treatment of constant land use. Land cover and land use should be fixed according to the LUH2 specifications for the constant land-use reference year (e.g., year 1850 for the DECK pre-industrial control simulation, year 2100 for ScenarioMIP extension simulations). The fraction of cropland and pastureland, as well as the crop type distribution, should be held constant. Any land management (e.g., irrigation, fertilization) that exists for the constant land-use year should be maintained at the same level. Wood harvesting for timber and shifting cultivation, specified by the LUH2 land-use reconstructions (i.e., through transition matrices or the mass of harvested wood), should be implemented if a model's land-use component permits these processes to be maintained through time at a specified level. If the fire model utilizes population density or other anthropogenic forcings to determine fire ignition and/or suppression rates, then this forcing should also be held constant. We recognize that the diversity of model approaches means that the definition and requirements for constant land management may differ across models. Groups will need to make their own decisions with respect to the treatment of land management in constant land-use scenarios, for example with respect to specification of harvesting on croplands, grazing on pastureland, application of fertilizers, level of irrigation, and wood harvest. Wood harvest, in particular, may require model-specific treatment since turning off wood harvest in the ScenarioMIP 2100-2300 extension runs is likely to result in unrealistic carbon stock trends, while maintaining wood harvest at year 2100 levels for an additional 200 years could unrealistically decimate the forests where the LUH2 data sets indicate wood harvest is happening in 2100. We stress that the individual modeling group decisions should be made within the context of achieving an equilibrated biogeophysical and biogeochemical (e.g., carbon, nitrogen) land state for the pre-industrial 1850 control configurations and to minimize any discontinuities in the shift between a constant land-use simulation and a subsequent transient land-use simulation (see the next paragraph for further clarification and discussion). Furthermore, the treatment of constant land use and land management should be clearly documented for each model and experiment. Because some land models are driven by annual maps of land use and others require transition rates between different land-use categories, LUMIP will provide two different 1850 constant land-use data sets - fraction of pastures and crops in 1850 and a onetime set of gross transitions from potential vegetation to the 1850 land-use state.
LUMIP acknowledges and endorses the need for flexible strategies to initialize CMIP6 historical simulations and DECK AMIP simulations. This flexibility is necessitated by (1) considerable structural differences among CMIP6participating land models, especially with respect to land use (e.g., models with and without wood harvest) and vegetation dynamics (e.g., prescribed vs. prognostic vegetation type and age distributions), (2) different spinup strategies for landonly models vs. coupled GCMs and ESMs (e.g., spinup for potential vegetation vs. constant 1850 land use), and (3) uncertainties in PI-Control experiments due to omission of documented secular multi-century trends in vegetation and soil carbon storage and land-use carbon emissions prior to 1850 (Pongratz et al., 2009; Sheviliakova et al., 2009). There are several strategies that have been used in the past and discussed by the modeling groups at the present time, including

- a "seamless" transition from the PI-control to historical as suggested by Jones et al. (2016); and

- a "bridge" experiment from an equilibrated ESM spinup with potential vegetation and subsequent application of a land-use scenario applied at a year prior to 1850 (Sentman et al., 2011; Shevliakova et al., 2013).

Consequently, LUMIP does not provide any recommendation on land initialization but requests that all modeling groups document their initialization procedure for their CMIP6 historical simulations and report any differences in biogeophysical and biogeochemical land states between the 1850 pre-industrial control and the beginning of the CMIP6 historical simulations in 1851. As noted above, a forum for discussion along with additional recommendations and clarifications with respect to initialization, the configuration of "constant land use", use of the LUH2 data, and other topics will be maintained through the LUMIP website (https: //cmip.ucar.edu/lumip).

\subsection{Phase 1 experiments}

Phase 1 consists of two sets of experiments: (a) an idealized coupled deforestation experiment that enables analysis of the biogeophysical and biogeochemical response to land-cover change and the associated changes in climate in a controlled and consistent set of simulations (Table 1) and (b) a series of offline land-only simulations to assess how the representation of land cover and land management affects the carbon, water, and energy cycle response to land-use change (Table 2).

\subsubsection{Global deforestation (deforest-glob, GCM, Tier 1, 80 years)}

Description: Idealized deforestation experiment in which 20 million $\mathrm{km}^{2}$ of forest area (covered by trees) is converted to natural grassland over a period of 50 years with a linear rate of $400000 \mathrm{~km}^{2}$ year ${ }^{-1}$, followed by 30 years of constant forest cover (Fig. 2a). This simulation should 
Table 1. Idealized deforestation experiment designed to gain process understanding and to assess biogeophysical role of land-cover change on climate and inter-compare modeled biogeochemical response to deforestation (concentration-driven).

\begin{tabular}{|c|c|c|c|}
\hline Experiment ID & Experiment name & Experiment description & Years \\
\hline deforest-glob & $\begin{array}{l}\text { Idealized transient } \\
\text { global deforesta- } \\
\text { tion }\end{array}$ & $\begin{array}{l}\text { Idealized deforestation experiment, } 20 \text { million } \mathrm{km}^{2} \text { forest removed lin- } \\
\text { early over a period of } 50 \text { years, with an additional } 30 \text { years with no spec- } \\
\text { ified change in forest cover (Tier } 1 \text { ). This simulation should be branched } \\
\text { from an } 1850 \text { control simulation ( piControl); all pre-industrial forcings } \\
\text { including } \mathrm{CO}_{2} \text { concentration and land-use maps and land management } \\
\text { should be maintained as in the piControl as discussed in Sect. } 2.1 \text {. }\end{array}$ & 80 years \\
\hline
\end{tabular}

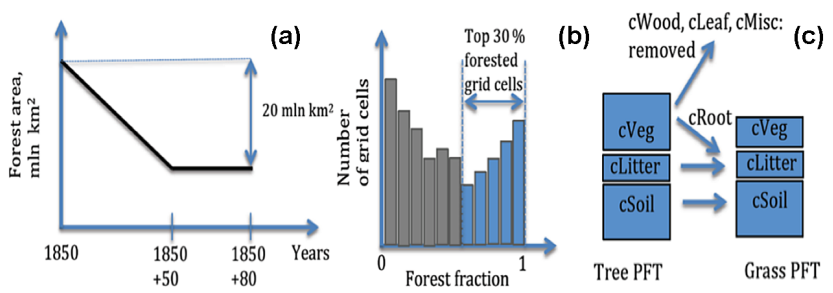

Figure 2. A schematic of the experimental setup in the deforest-glob experiment. (a) Scenario of forced changes in the global forest area. (b) Sorting and selection of the grid cells that should be deforested. (c) Transition of carbon pools after deforestation.

be branched from an 1850 control simulation (piControl); all pre-industrial forcings including $\mathrm{CO}_{2}$ concentration and land-use maps and land-management should be maintained as in the piControl and discussed in Sect. 2.1. The branch should occur at least 80 years prior to the end of the piControl simulation so that deforest-glob and piControl can be directly compared. In order to concentrate the deforestation from grid cells with predominant forest cover, deforestation should be restricted to the top $30 \%$ of land grid cells in terms of their area of tree cover. Effectively, this concentrates the deforestation in the tropical rainforest and boreal forest regions (Fig. 3). To do this:

1. Sort land grid cells by forest area and select the top $30 \%$ (gcdef, Fig. 2b).

2. Calculate tree plant type loss for each year at each grid cell by attributing the $400000 \mathrm{~km}^{2}$ year ${ }^{-1}$ forest loss proportionally to their forest cover fraction across the gcdef grid cells.

Step 2 is formalized as follows. Let $f(x, y, t)$ be the forest fraction in grid cell $(x, y)$ at the end of year $t(0 \leq t \leq 80)$; $A(x, y)$ is the area of the grid cell (million $\left.\mathrm{km}^{2}\right)$. At $t=$ 0 (initialization of deforest-glob), forest fraction should be equal to that of year 1850 in the piControl. The total forest area, $F_{\text {tot }}\left(\right.$ million $\left.\mathrm{km}^{2}\right)$, within the grid cells identified for deforestation (gcdef) in Step 1 is

$F_{\text {tot }}=\sum_{g c d e f} f(x, y, t=0) A(x, y)$.
If $F_{\text {tot }}$ is more than 20 million $\mathrm{km}^{2}$, then the scaling coefficient $k_{\text {gcdef }}$ is

$k_{\text {gcdef }}=\frac{20}{F_{\text {tot }}} \leq 1$

and temporal development of forest fraction in deforested grid cells is calculated as follows:

$f(x, y, t)= \begin{cases}f(x, y, t=0)\left(1-\frac{k_{\text {gcdef }} t}{50}\right) & 0<t \leq 50 \\ f(x, y, t=0)\left(1-k_{\text {gcdef }}\right) & t>50\end{cases}$

If $F_{\text {tot }}$ is less than or equal to 20 million $\mathrm{km}^{2}$, then the scaling coefficient $k_{\text {cgef }}$ is taken as 1 .

Trees should be replaced with natural unmanaged grasslands. Land use and land management should be maintained at 1850 levels as in the piControl experiment. All above ground biomass (cWood, cLeaf, cMisc) should be removed and below ground biomass (cRoot) transferred to appropriate litter pools (Fig. 2c). If there is no separation of above and below ground biomass in the model, then the whole vegetation biomass pool (cVeg) should be removed. The replacement of forest with natural grasslands should be done in such a way that the carbon (and nitrogen if applicable) from the forested soil is maintained and allowed to evolve according to natural model processes. If initial forest cover in the gcdef grid cells is less than 20 million $\mathrm{km}^{2}$ then should linearly remove all the forested area from the $g c d e f$ grid cells over 50 years and report the total area of forest removed. Note that even with substantially different initial forest cover in CCSM4 vs. MPIESM-P (the examples shown in Fig. 3), the prescribed landcover change is quite similar for both models when using this deforestation protocol and that modelling groups should strive to produce similar deforestation patterns.

Note that implementation of the deforestation is likely to differ for models with and without vegetation dynamics. Applying deforestation for models without dynamic vegetation should be straightforward as the deforestation can be applied through a time series of land-cover maps that each group can generate. For models with dynamic vegetation, if possible, vegetation dynamics should be turned off in areas where deforestation is being applied. Outside the deforested areas, vegetation dynamics can be maintained since the tree cover 
Table 2. Land-only land-cover, land-use, and land-management change simulations. Assess relative impact of land-cover, land-use, and land-management change on fluxes of water, energy, and carbon; forced with historical observed climate. The simulations land-hist, landhist-altStartYear and land-noLu are Tier 1, all other simulations are Tier 2. All simulations should be pre-industrial to 2015, where the pre-industrial start can be either 1850 or 1700 , depending on the model.

\begin{tabular}{lll}
\hline Experiment ID & Description & Notes \\
\hline land-hist & Same land model configuration, including representa- & This simulation can and likely will be a different con- \\
& tion of land cover, land use, and land management, as & figuration across models due to different representa- \\
& used in coupled CMIP6 historical simulation with all & tions of land use for each model. See the LS3MIP pro- \\
& applicable land-use features active. Start year either & tocol for full details, including details of the forcing \\
& 1850 or 1700 depending on standard practice for par- & data set and spinup. \\
& ticular model. All forcings transient including $\mathrm{CO}_{2}$, &
\end{tabular}

$\mathrm{N}$-deposition, aerosol deposition, etc. Shared simulation with LS3MIP.

\begin{tabular}{ll}
\hline land-hist-altStartYear & $\begin{array}{l}\text { Same as land-hist except starting from either 1700 (for } \\
\text { models that typically start in 1850) or } 1850 \text { (for mod- } \\
\text { els that typically start in 1700). }\end{array}$ \\
\hline land-noLu & $\begin{array}{l}\text { Same as land-hist except no land-use change (see } \\
\text { Sect. } 2.1 \text { for explanation of no land use). }\end{array}$ \\
\hline land-hist-altLu1 & Same as land-hist except with two alternative land-use \\
history reconstructions, that span uncertainty in agri- \\
culture and wood harvest. Specifically, the altLul is \\
a "high" reconstruction, assumes high historical esti- \\
mates for crop and pasture and wood harvest and al- \\
\\
$\begin{array}{l}\text { tLu2 is a "low" reference assumes low estimates for } \\
\text { each of these terms, relative to the reference data set. }\end{array}$
\end{tabular}

Comparison to land-hist indicates impact of pre-1850 land-use change.

In combination with land-hist, allows assessment of model sensitivity to different assumptions about landuse history reconstructions. Note that land use in 1700 and 1850 will be different to that in land-hist so model will need to be spun up again for both alternative data sets. Note that these reconstructions do not span the entire range of uncertainty, and the simulations should be considered sensitivity simulations.

\begin{tabular}{ll}
\hline land-cCO2 & Same as land-hist except with $\mathrm{CO}_{2}$ held constant \\
\hline land-cClim & Same as land-hist except with climate held constant \\
\hline land-crop-grass & $\begin{array}{l}\text { Same as land-hist but with all new crop and pasture- } \\
\text { land treated as unmanaged grassland }\end{array}$
\end{tabular}

land-crop-noIrrigFert

Same as land-hist except with plants in cropland area utilizing at least some form of crop management (e.g., planting and harvesting) rather than simulating cropland vegetation as a natural grassland... Irrigated area and fertilizer area/use should be held constant.

land-crop-noIrrig $\quad$ Same as land-hist but with irrigated area held at 1850 levels; only relevant if land-hist utilizes at least some form of crop management (e.g., planting and harvest-

Continue with spinup forcing looping over first 20 years of meteorological forcing data.

For this simulation, treat cropland like natural grassland without any crop management in terms of biophysical properties but is treated as agricultural land for dynamic vegetation (i.e., no competition with natural vegetation areas).

Maintain 1850 irrigated area and fertilizer area/amount and without any additional crop management except planting and harvesting. Irrigation amounts with irrigated area allowed to change.

Maintain 1850 irrigated area. Irrigation amounts within the 1850 irrigated area allowed to change ing)

land-crop-noFert $\quad$ Same as land-hist but with fertilization rates and area held at 1850 levels/distribution; only relevant if landhist utilizes at least some form of crop management (e.g., planting and harvesting)

land-noPasture Same as land-hist but with grazing and other management on pastureland held at 1850 levels/distribution; i.e., all new pastureland is treated as unmanaged grassland (as in land-crop-grass). 
Table 2. Continued.

\begin{tabular}{lll}
\hline Experiment ID & Description & Notes \\
\hline land-noWoodHarv & $\begin{array}{l}\text { Same as land-hist but with wood harvest maintained } \\
\text { at } 1850 \text { amounts/areas }\end{array}$ & $\begin{array}{l}\text { Wood harvest due to land deforestation for agricul- } \\
\text { ture should continue yielding non-zero anthropogenic } \\
\text { product pools }\end{array}$ \\
\hline land-noShiftcultivate & $\begin{array}{l}\text { Same as land-hist except shifting cultivation turned } \\
\text { off. Only relevant for models where default model } \\
\text { treats shifting cultivation (see Fig. 4) }\end{array}$ & $\begin{array}{l}\text { An additional LUC transitions data set will be pro- } \\
\text { vided as a data layer within the LUMIP LUH2 data } \\
\text { set with shifting cultivation deactivated. }\end{array}$ \\
\hline land-noFire & $\begin{array}{l}\text { Same as land-hist but with anthropogenic ignition and } \\
\text { suppression held to 1850 levels }\end{array}$ & $\begin{array}{l}\text { For example, if ignitions are based on population } \\
\text { density, maintain constant population density through } \\
\text { simulation }\end{array}$ \\
\hline
\end{tabular}

response to the climate change induced by deforestation is expected to be small over the 80-year simulation timescale.

We recognize that each participating land model has its own unique structures that may or may not be adequately covered in the above description sketched on the Fig. 2. Each modelling group should implement the deforestation in a manner that makes the most sense for their particular modelling system. It is important, however, that all groups strive to produce a spatial and latitudinal deforestation signal that replicates that shown in Fig. 3 as closely as possible. The goal of this experiment is to impose deforestation patterns that are as similar as possible across models so as to limit the impact of across-model differences in deforestation patterns on the multi-model evaluation of deforestation impacts on climate and carbon fluxes.

Rationale: this experiment is designed to be conceptually analogous to the $1 \%$ year ${ }^{-1} \mathrm{CO}_{2}$ simulation in the DECK. Prior idealized global or regional deforestation simulations (Badger and Dirmeyer, 2015, 2016; Bala et al., 2007; Bathiany et al., 2010; Davin and de Noblet-Ducoudré, 2010; Lorenz et al., 2016; Snyder, 2010) have proven informative and highlighted how both biogeophysical and biogeochemical forcings due to land-use change contribute to temperature changes, how the ocean can modulate the response, and how remote effects of LULCC can be detected in some situations. However, differences in implementation of realistic historic or projected land-cover change across different models is a problem that has plagued prior land-cover change model intercomparison projects, with a third to a half - depending on season and variable - of the differences in climate response attributable to differences in imposed land cover (Boisier et al., 2012). The relatively simple LUMIP idealized deforestation protocol will enhance uniformity in the prescribed deforestation and therefore enable more direct and meaningful comparison of model responses to deforestation. The gradual deforestation allows a comparison across models with respect to what amplitude of forest loss is needed before a detectable signal emerges at the local and global level, and will provide insight into detection and attribution of land-cover change impacts at regional scales.

\subsubsection{Land-only land-cover and land-use simulations (land-xxxx, land-only; land-hist, land-hist-altStartYear and land-noLu are Tier 1, all others Tier 2, up to 13 simulations, 165 to 315 years each).}

Description: a set of land-only simulations that are identical to the LS3MIP (van den Hurk et al., 2016) historical land-only (land-hist; Table 2) simulation except with each simulation differing from the land-hist simulation in terms of the specific treatment of land use or land management, or in terms of prescribed climate. Note that all simulations should be forced with the default reanalysis data set provided through LS3MIP (GSWP3 at time of writing). The primary control experiment is land-hist; this is defined in LS3MIP. This experiment is required (Tier 1), even if the modeling group is not contributing to the full set of LS3MIP experiments. The land-hist simulation should include land cover, land use, and land management that are identical to that used in the coupled CMIP6 historical simulation (see the next paragraph for more discussion). Two of the LUMIP simulations - land-hist-altStartYear and land-hist-noLu - are Tier 1. The remaining experiments are Tier 2. Detailed descriptions of the factorial set of simulations are listed in Table 2.

We anticipate that only a limited number of participating land models will be able to perform all the experiments, but the experimental design allows for models to submit the subset of experiments that are relevant for their model. In some instances, groups may also have a more advanced land model in terms of its representation of land-use-related processes than that which is used in the coupled CMIP6 historical simulation. In these cases, we request that models submit the LUMIP Tier 1 land-only experiments with the configuration of the land model used in the coupled model CMIP6 historical simulation, but groups are encouraged to provide an additional set of land-only simulations with their more advanced model configuration.

Rationale: this factorial series of experiments serves several purposes and is designed to provide a detailed assessment of how the specification of land-cover change and land 

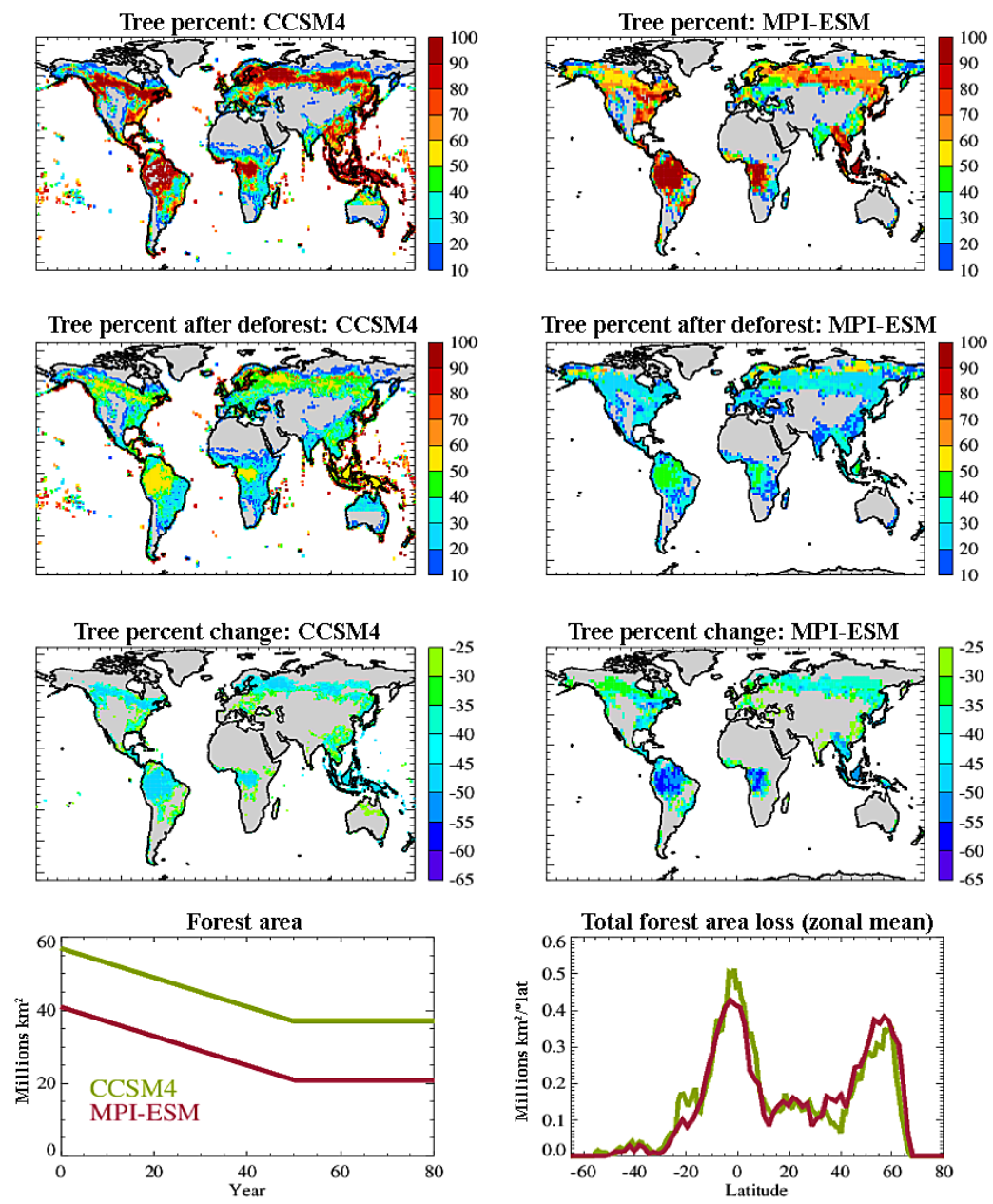

Figure 3. Sample maps of fraction of grid cell covered by trees at the start of the idealized deforestation simulation, after idealized deforestation (year 50), and the change in tree fraction by the end of the deforestation period. Time series of forest area and zonal mean forest area loss are also shown. Examples are shown for two typical CMIP5 models with strongly differing initial forest cover. Even with the different initial forest cover, the deforestation patterns and amounts are broadly equivalent across the two models.

management affects the carbon, water, and energy cycle response to land-use change. This set of experiments utilizes state-of-the-art land-model developments that are planned across several contacted modeling centers and will contribute to the setting of priorities for land use for future CMIP activities. The potential analyses that will be possible through this set of experiments are vast. We highlight several particular analysis foci here.

The land-hist and land-noLu simulations will provide context for the global coupled CMIP6 historical simulations, enabling the disentanglement of the LULCC forcing (changes in water, energy and carbon fluxes due to land-use change) from the response (changes in climate variables such as temperature and precipitation that are driven by LULCC-induced surface flux changes), though differences in the coupled model and observed climate forcing will need to be taken into account. The land-only simulations also allow more detailed quantification of the net LULCC flux.
Relative influence of various aspects of land management on the overall impact of land use on water, energy, and carbon fluxes. For example, comparing the land-hist experiment to the experiment with no irrigation (land-crop-noirrig) will allow a multi-model assessment of whether or not the increasing use of irrigation during the 20th century is likely to have significantly altered trends of regional water and energy fluxes (and therefore climate) or crop yield/carbon storage in agricultural regions.

Pre-industrial land conversion for agriculture was substantial (Pongratz et al., 2008) and has long-term and nonnegligible legacy effects on the carbon cycle that last well beyond the standard 1850 starting year of CMIP6 historical simulations (Pongratz and Caldeira, 2012). By comparing land-hist with land-hist-altStartYear across a range of models, we can further establish how important pre-1850 land use is for the historical (1850-2005) land carbon stock trajectory. 


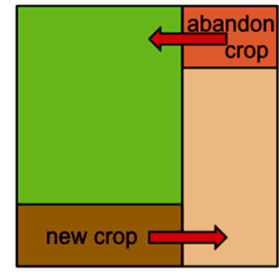

shifting cultivation (gross LU transition)

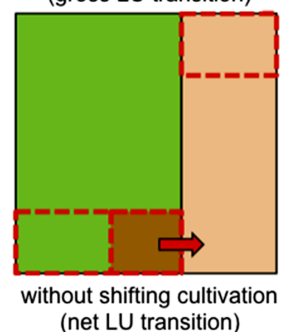

(net LU transition)

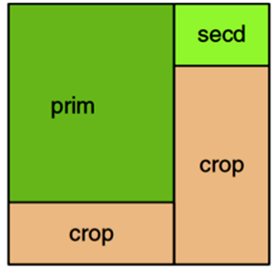

state after gross transition

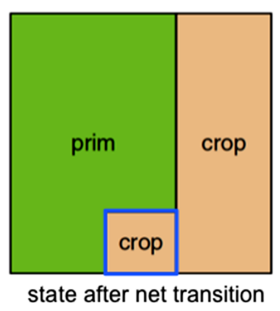

Figure 4. Schematic diagram showing difference between inclusion of shifting cultivation (gross transitions) vs. exclusion of shifting cultivation (net transitions). Where shifting cultivation is included (upper row), new cropland (or pastureland) is taken (deforestation) from primary land ("prim") and abandoned to secondary land ("secd") in parallel within a grid cell. In this case carbon fluxes, for example, are captured for each transition. Where shifting cultivation is not represented (lower row), only the difference of new cropland minus abandoned cropland (represented by crop area outlined in blue in bottom right figure) undergoes a transition to cropland and no cropland is abandoned to form secondary land. In this case, a smaller grid cell area fraction is affected by LUC. Adapted from Fig. 1 of Stocker et al. (2014).

Gross land-use transitions, especially due to shifting cultivation, can exceed net transitions by a factor of 2 or more (Hurtt et al., 2011). Accounting for gross transitions instead of just net transitions results in 15-40\% higher simulated net land-use carbon fluxes (Hansis et al., 2015; Stocker et al., 2014; Wilkenskjeld et al., 2014). For models that can represent shifting cultivation, a parallel experiment (lnd-histnoShiftcultivate) in which shifting cultivation is turned off (net transition) through an alternative set of provided landuse transitions will allow evaluation of the impact of shifting cultivation across a range of models and assumptions (Fig. 4).

Comparison of effects of LULCC on surface climate and carbon fluxes (which can be calculated by comparing historical and no-LULCC simulations) between the landonly simulations and the global coupled model simulations (Sect. 2.3.1) allows assessment of consequences of model climate biases on LULCC effects.

Uncertainty in the land-use history reconstruction is itself a source of uncertainty in the impacts of historic LULCC. The alternative land-use history simulations (landhist-altLu1 and land-hist-altLu2) in combination with the default land-use history simulation (land-hist) provide informa- tion on the sensitivity of the models to a range of plausible reconstructions of land-use history.

Impact of historic meteorological forcing data sets: it is critical to acknowledge that all observed historic forcing data sets are subject to considerable errors and uncertainty and that the weather and climate variability and trends represented in these data sets may not accurately reflect reality, especially in remote regions where limited data went into either the underlying reanalysis or the gridded products. These limitations pose a challenge when comparing the model outputs (like latent heat flux, for example) to observed estimates because biases may actually be a function of biases in the meteorological forcing data set rather than deficiencies in the model. While the land-only LUMIP simulations will only be driven with a single atmospheric forcing data set (the reference data set used in the land-hist experiment of LS3MIP), the sensitivity of land model output to uncertainty in atmospheric forcing will be assessed in more depth within LS3MIP, which can inform the assessment of the land-only LUMIP simulations.

\subsection{Phase 2 experiments}

The Phase 2 LUMIP experiments are designed to provide a multi-model quantification of the impact of historic LULCC on climate and carbon cycling and to assess the extent to which land management could be utilized as a climate change mitigation tool. This set of experiments includes land-only and coupled historical and future simulations that are derivatives of historical or future simulations within LS3MIP, ScenarioMIP, C4MIP as well as the CMIP6 Historical simulation with land use held constant or modified to an alternative land-use scenario (Table 3). These simulations will be used to assess the role of land use on climate from the perspective of both the biogeophysical and biogeochemical impacts and are likely to be of interest to DAMIP, C4MIP, ScenarioMIP, and LS3MIP.

\subsubsection{Historical no land-use change experiment (hist-noLu; concentration-driven, Tier 1, 165 years)}

Description: historical simulation that is identical to the CMIP6 historical concentration-driven simulation, except that land use is held constant. All land use and management (irrigation, fertilization, wood harvest, gross transitions exceeding net transitions) is maintained at 1850 levels, in exactly the same way as done for the CMIP6 pre-industrial control simulation (piControl).

Rationale: this simulation, when compared to the CMIP6 historical simulation, isolates the biogeophysical impact of land-use change on climate and addresses the CMIP6 science question "How does the Earth system respond to forcing?" For models that are run with a diagnostic land carbon cycle, the difference in carbon stocks between hist-noLu and 
Table 3. Coupled Model Phase 2 simulations, all Tier 1.

\begin{tabular}{llll}
\hline Experiment ID & Experiment name & Experiment description & Years \\
\hline hist-noLu & $\begin{array}{l}\text { Historical with no land- } \\
\text { use change }\end{array}$ & $\begin{array}{l}\text { Same as concentration-driven CMIP6 historical (Tier 1) except with } \\
\text { LULCC held constant. See Sect. 2.1 for explanation of no land use. } \\
\text { Two additional ensemble members requested in Tier 2. }\end{array}$ \\
\hline $\begin{array}{llll}\text { ssp370- } \\
\text { ssp126Lu }\end{array}$ & $\begin{array}{l}\text { SSP3-7 with SSP1-2.6 } \\
\text { land use }\end{array}$ & $\begin{array}{l}\text { Same as ScenarioMIP ssp370 (SSP3-7 deforestation scenario, Tier 1) } \\
\text { except use land use from ssp126 (SSP1-2.6 afforestation scenario); } \\
\text { concentration-driven. Two additional ensemble members requested } \\
\text { (Tier 2) contingent on ScenarioMIP ssp370 large ensemble (Tier 2) be- }\end{array}$ \\
& $\begin{array}{l}\text { ing completed } \\
\text { ssp126- }\end{array}$ & $\begin{array}{l}\text { SSP1-2.6 with SSP3-7 } \\
\text { ssp370Lu }\end{array}$ & $\begin{array}{l}\text { Same as ScenarioMIP ssp126 (SSP1-2.6 afforestation scenario, Tier 1) } \\
\text { except use land use from ssp370 (SSP3-7 deforestation scenario); } \\
\text { concentration-driven. }\end{array}$ \\
\hline $\begin{array}{l}\text { land use } \\
\text { ssp126Lu }\end{array}$ & $\begin{array}{l}\text { Emissions-driven } \\
\text { SSP5-8.5 with SSP1- }\end{array}$ & $\begin{array}{l}\text { Same as C4MIP esm-ssp585 (Tier 1) except use SSP1-2.6 land use (af- } \\
\text { forestation scenario); emissions-driven }\end{array}$ \\
\hline
\end{tabular}

the CMIP6 historical simulation represents the integrated net LULCC flux. Note that the parallel set of land-only simulations (LS3MIP land-hist experiment and LUMIP land-noLu experiment; see Sect. 2.1.3) will enable groups to disentangle the contributions of land-use change-induced effects on surface fluxes from atmospheric feedbacks and response (e.g., Chen and Dirmeyer, 2016), though the influence of differences in land forcing in coupled vs. land-only simulations will need to be taken into account during the analysis. This experiment is directly relevant for detection and attribution studies (DAMIP).

\subsubsection{Future land-use policy sensitivity experiments (ssp370-ssp126Lu and ssp126-ssp370Lu, GCM concentration-driven, Tier 1, 2015-2100; esm-ssp585-ssp126Lu, ESM emission-driven, Tier 1, 2015-2100)}

Description: these experiments are derivatives of ScenarioMIP (ssp370 and ssp126; see below for a short description of the Shared Socioeconomic Pathways (SSP) land-use scenarios) and C4MIP (esm-ssp85) simulations (Fig. 5). In each case, the LUMIP experiment is identical to the "parent" simulation, except that an alternative land-use data set is used. All other forcings are maintained from the parent simulation.

Rationale: both concentration-driven and emission-driven LUMIP alternative land-use simulations are requested. Concentration-driven variants of ScenarioMIP ssp370 and ssp126 are required, but each uses the land-use scenario from the other: i.e., LUMIP simulation ssp370-ssp126Lu will run with all forcings identical to ssp370, except for land use, which is to be taken from ssp126. These simulations permit analysis of the biogeophysical climate impacts of projected land use and enable preliminary assessment of land use and land management as a regional climate mitigation tool (green

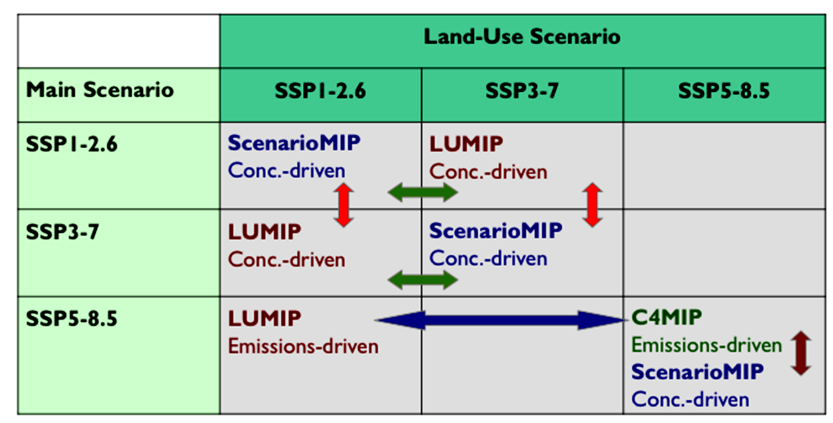

Figure 5. Schematic describing the future land-use policy sensitivity experiments. Green arrows indicate set of experiments that permit analysis of the biogeophysical climate impacts of projected land use and enable assessment of land management as a regional climate mitigation tool. Red arrows indicate set of experiments that allow study of how the impact of land-use change differs at different levels of climate change and at different levels of $\mathrm{CO}_{2}$ concentration. Blue arrow indicates set of experiments that will enable quantification of the full effects of a different land-use scenario through both biophysical and biogeochemical processes. Brown arrows indicate set of experiments that allow quantification of the effects of the climate-carbon cycle feedback on future $\mathrm{CO}_{2}$ and climate change.

arrows in Fig. 5). Note that these simulations should be considered sensitivity simulations since they will include a set of forcings that are inconsistent with each other (e.g., land use from SSP1-2.6 in a simulation that in all other respects is equivalent to SSP3-7). This particular set of simulations was selected because the projected land-use trends in SSP37 and SSP1-2.6 diverge strongly, with SSP3-7 representing a reasonably strong deforestation scenario and SSP1-2.6 including significant afforestation (see Fig. 6). These experiments will provide a direct test of an assumption underlying the SSP framework, namely that a particular radiative forc- 
ing level can be achieved by multiple socioeconomic scenarios with a negligible effect on the resulting climate (Van $\mathrm{Vu}$ uren et al., 2014), an assumption that may not hold if patterns of land-use change associated with alternative SSPs diverge significantly enough from one another (Jones et al., 2013b). Furthermore, including experiments in both low and medium/high radiative forcing scenarios allows examination of the extent to which the impact of land-use change differs at different levels of climate change and at different levels of $\mathrm{CO}_{2}$ concentration (red arrows in Fig. 5). These sets of experiments can be utilized to provide partial guidance on the utility of careful land management as a climate mitigation strategy (Canadell and Raupach, 2008; Marland et al., 2003).

Emission-driven simulations allow assessment of the full feedback (biogeophysical + biogeochemical) due to land-use change onto climate. In these simulations the ESMs simulate the concentration of atmospheric $\mathrm{CO}_{2}$ in response to prescribed boundary conditions of anthropogenic emissions. Biogeophysical effects operate in the same way as in concentration-driven simulations but, in addition, the carbon released or absorbed due to land-use change will affect how the $\mathrm{CO}_{2}$ concentration of the atmosphere evolves in time. Additionally, emission-driven simulations permit assessment of consistency between Integrated Assessment Model predictions (which typically include the biogeochemical effect of land use as a carbon source but neglect the biophysical effects) about land use and land-use change carbon fluxes with ESM modeled land-use emissions. C4MIP has requested an emission-driven variant to $s s p 585$, which will be performed in concentration-driven mode for ScenarioMIP. This will allow quantification of the effects of the climate-carbon cycle feedback on future $\mathrm{CO} 2$ and climate change (brown arrow in Fig. 5). In LUMIP we request a further SSP5-8.5 simulation: emission-driven but with land use taken from SSP1-2.6. This experiment (esm-ssp585-ssp126Lu) will therefore parallel the C4MIP emission-driven experiment (esm-ssp585) but will allow us to quantify the full effects of a different land-use scenario through both biophysical and biogeochemical processes (blue arrow in Fig. 5).

Land-use scenarios in SSPs: the scenarios chosen for use in CMIP6 were developed as part of the Shared Socioeconomic Pathways (SSPs) effort (Van Vuuren et al., 2014). Five SSPs were designed to span a range of challenges to mitigation and challenges to adaptation. These SSPs can be combined with RCPs to provide a set of scenarios that span a range of socioeconomic assumptions and radiative forcing levels (Riahi et al., 2016). ScenarioMIP selected eight scenarios from this suite for use in CMIP6. Within LUMIP, we focus on three of these scenarios in our experimental design, chosen because they span a range of future land-use projections. The SSP5-8.5 is a high radiative forcing scenario, reaching $8.5 \mathrm{~W} \mathrm{~m}^{-2}$ in 2100 , with relatively little land-use change over the coming century. The increase in radiative forcing is driven by increased use of fossil fuels; however, the combination of a relatively small population and high agricultural yields leads to little expansion of cropland area (Kriegler et al., 2016). In contrast, the SSP3-7 is a world with a large population and limited technological progress, resulting in expanded cropland area (Fujimori et al., 2016). In the SSP1-2.6, efforts are made to limit radiative forcing to $2.6 \mathrm{~W} \mathrm{~m}^{-2}$. These mitigation efforts include reduced deforestation as well as reforestation and afforestation, leading to a scenario where forest cover increases over the coming century (Van Vuuren et al., 2016). Figure 6 shows global time series of forest area, cropland area, pastureland area, wood harvest, area equipped for irrigation, and nitrogen fertilization amounts in the SSP scenarios, highlighting those scenarios selected by ScenarioMIP and LUMIP.

\section{Land-use metrics and analysis plans}

\subsection{Land-use metrics}

A goal of LUMIP is to establish a useful set of model diagnostics that enable a systematic assessment of land useclimate feedbacks and improved attribution of the roles of both land and atmosphere in terms of generating these feedbacks. The need for more systematic assessment of the terrestrial and atmospheric response to land-cover change is one of the major conclusions of the LUCID studies. Boisier et al. (2012) and de Noblet-Ducoudré et al. (2012) argue that the different land use-climate relationships displayed across the LUCID models highlight the need to improve diagnostics and metrics for land surface model evaluation in general and the simulated response to LULCC in particular. These sentiments are consistent with recent efforts to improve and systematize land model assessment (e.g., Abramowitz, 2012; Best et al., 2015; Kumar et al., 2012; Luo et al., 2012; Randerson et al., 2009). LUMIP will promote a coordinated effort to develop biogeophysical and biogeochemical metrics of model performance with respect to land-use change that will help constrain model dynamics. These efforts dovetail with expanding emphasis in CMIP6 on model performance metrics. Several recent studies have utilized various methodologies to infer observationally based historical change in land surface variables impacted by LULCC or divergences in surface response between different land-cover types (Boisier et al., 2013, 2014; Lee et al., 2011; Lejeune et al., 2016; Li et al., 2015; Teuling et al., 2010; Williams et al., 2012).

The availability of both land-only and coupled historic simulations enables a more systematic assessment of the roles of land and atmosphere in the simulated response to land-use change. With both coupled and uncoupled experiments with and without land-use change, we can systematically disentangle the simulated LULCC forcing (changes in land surface water, energy and carbon fluxes due to land-use change) from the response (changes in climate variables such as $T$ and $P$ that are driven by LULCC-driven changes in surface fluxes). 

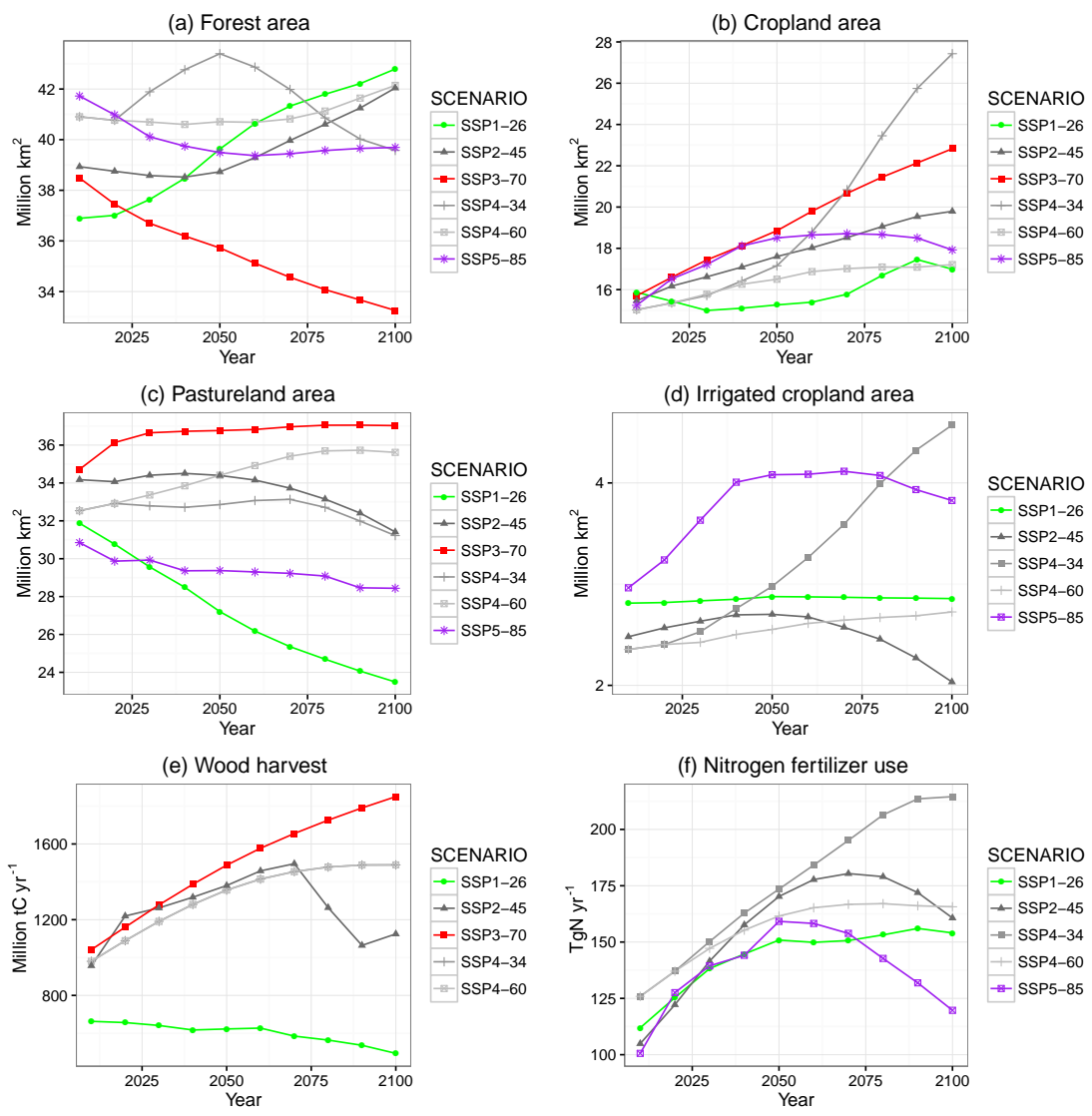

Figure 6. Global time series of land cover (a), land use (b, c, e), and land management (d, f) for the future simulations. Lines indicate SSP-RCP scenarios chosen for ScenarioMIP, with colored lines representing scenarios with specific LUMIP experiments. Data is provided by the IAM community. Data will be harmonized to ensure consistency between the end of the historical period and the beginning of the projection period for each of the scenarios. Note that not all IAMs predict all the LUH2 land management quantities (e.g., wood harvest is missing for SSP5-8.5). The missing land management variables will be generated during the harmonization process in a manner that is consistent with the underlying scenario.

LUMIP also proposes to develop a set of analysis metrics that succinctly quantify a model response to land use across a range of spatial scales and temporal scales that can then be used to quantitatively compare model response across different models, regions, and land-management scenarios. For a given variable, say surface air temperature, diagnostic calculations will be completed for a pair of simulations (offline or coupled) with and without land-use change. Across a range of spatial scales, spanning from a single grid cell up to regional, continental, and global, seasonal mean differences between control and land-use change simulations will be examined. Differences will be expressed, for example, both in terms of seasonal mean differences and in terms of signal to noise (where "noise" refers to the natural interannual climate variability simulated in the model). Lorenz et al. (2016) emphasize the importance of testing for field significance, especially in the context of evaluating the statistical significance of remote responses to LULCC.

\subsection{Net LULCC carbon flux: loss of additional sink capacity and the net land-use feedback}

To quantify the climatic and carbon cycle consequences of LULCC and land management consistently across models, care has to be taken that the same conceptual framework is applied. Pongratz et al. (2014) have highlighted this issue for the net LULCC carbon flux. The large spread in published estimates of the net LULCC flux can be substantially attributed to differing definitions that arise from different model and simulation setups. These definitions differ in particular with respect to the inclusion of two processes, the loss of additional sink capacity (LASC) and the land-use carbon feedback. The LASC, which is an indirect LULCC flux, occurs when conversion of land from natural lands (forests) to managed lands (crops or pasture) reduces the capacity of the land biosphere to take up anthropogenic carbon dioxide in the future (e.g., Gitz and Ciais, 2003). While small historically it may be of the same order as the net LULCC flux without LASC for future scenarios of strong $\mathrm{CO}_{2}$ in- 
crease (Gerber et al., 2013; Mahowald et al., 2016; Pongratz et al., 2014). The land-use carbon feedback can be assessed in emission-driven simulations where LULCC carbon fluxes alter the atmospheric $\mathrm{CO}_{2}$ concentration and the land-use changes also affect the climate through biogeophysical responses, both of which can then feed back onto the productivity of both natural and managed vegetation. Over the historical period, a substantial fraction of the LULCC emissions have been offset with increased vegetation growth. Calculating the net LULCC flux by differencing carbon stocks from a pair of simulations with and without LULCC will lead to net LULCC flux estimates that are about 20-50\% lower when calculated from a pair of emission-driven simulations (which include the land use-carbon feedback) compared to a pair of land-only simulations (Pongratz et al., 2014; Stocker and Joos, 2015).

Within LUMIP, several different model configurations are used that include the LASC and the land use-carbon feedback to different extents (Fig. 7). Note that to isolate the effect of LULCC emissions from those of fossil-fuel emissions, a reference simulation is needed, which may be a no-LULCC simulation or a simulation with an alternative LULCC scenario. In the case of the idealized deforestation experiments, where $\mathrm{CO}_{2}$ is kept constant over time, all changes in carbon stocks can be directly attributed to LULCC. The net LULCC flux, as quantified from the landonly simulation, will differ slightly from that calculated in GCM simulations since the GCM simulations include biogeophysical climate feedbacks from LULCC. The difference in net LULCC flux between two LULCC scenarios as derived from the ESM setup follows a different definition, as the land-use carbon feedback is included and its effects cancel only partly by difference of the two simulations.

\subsection{Radiative forcing}

A recognized limitation within CMIP5 was the difficulty in diagnosis of the radiative forcing due to different forcing mechanisms such as well-mixed GHGs, aerosols or land-use change. In addition, the regionally concentrated nature of biophysical land-use forcing limits the insight gained from quantifying it in terms of a global mean metric (or more strictly the effective radiative forcing, ERF; Davin et al., 2007; Jones et al., 2013a; Myhre et al., 2013). Experiments were performed within CMIP5 to explore different model responses to individual forcings but were not designed to distinguish how each forcing led to a radiative forcing of the climate system vs. how the climate system responded to that forcing. For CMIP6, RFMIP is designed to address this gap by including a factorial set of atmosphere-only simulations to diagnose the ERF due to each forcing mechanism individually. Andrews et al. (2016) performed the Radiative Forcing MIP (RFMIP) land-use experiment to diagnose the historical ERF from land use in HadGEM2-ES and found a forcing of $-0.4 \mathrm{~W} \mathrm{~m}^{-2}$ or about $17 \%$ of the total present-day anthropogenic radiative forcing. Other studies indicate that the combined radiative forcing effect of land-use change may be as large as $\sim 40 \%$ of total present-day anthropogenic radiative forcing, when accounting for emissions of all GHG species due to LULCC (Ward et al., 2014). LUMIP will benefit from groups performing the RFMIP land-use experiment in addition to the LUMIP simulations.

\subsection{Modulation of the land-use change signal by land-atmosphere coupling strength}

An axis of analysis that has not been investigated in great detail is how a particular model's regional land-atmosphere coupling strength signature (Guo et al., 2006; Koster et al., 2004; Seneviratne et al., 2010, 2013) affects simulations of the climate impact of land-use change. One can hypothesize that LULCC in a region where the land is tightly coupled to the atmosphere, generally due to the presence of a soil moisture-limited evapotranspiration regime (Koster et al., 2004; Seneviratne et al., 2010), will result in a stronger climate response than the same LULCC in a region where the atmosphere is not sensitive to land conditions. In a single model study of Amazonian deforestation, Lorenz and Pitman (2014) find that this is indeed the case - small amounts of deforestation in a part of the Amazon domain where the model simulates strong land-atmosphere coupling has a larger impact on temperature than extensive deforestation in a weakly coupled region. Similarly, Hirsch et al. (2015) show that different planetary boundary layer schemes, which lead to different land-atmosphere coupling strengths, can modulate the impact of land-use change on regional climate extremes. LUMIP will collaborate with LS3MIP to systematically investigate the inter-relationships between landatmosphere coupling strength, which can be diagnosed in any coupled simulation (e.g., Dirmeyer et al., 2014; Seneviratne et al., 2010), and LULCC impacts on climate, and establish to what extent differences in land-atmosphere coupling strength across models (Koster et al., 2004) contribute to differences in modeled LULCC impacts.

\subsection{Extremes}

There is evidence that land surface processes strongly affect hot extremes, as well as drought development and heavy precipitation events, in several regions (Davin et al., 2014; Greve et al., 2014; Seneviratne et al., 2010, 2013), and that these relationships could also change with increasing greenhouse gas forcing (Seneviratne et al., 2006; Wilhelm et al., 2015). Therefore, the role of LULCC needs to be better investigated, both in the context of the detection and attribution of past changes in extremes (Christidis et al., 2013) - in coordination with DAMIP - and in assessing its impact on projected changes in climate extremes. In particular, recent studies show that LULCC could affect temperature extremes more strongly than mean temperature, through a combination 


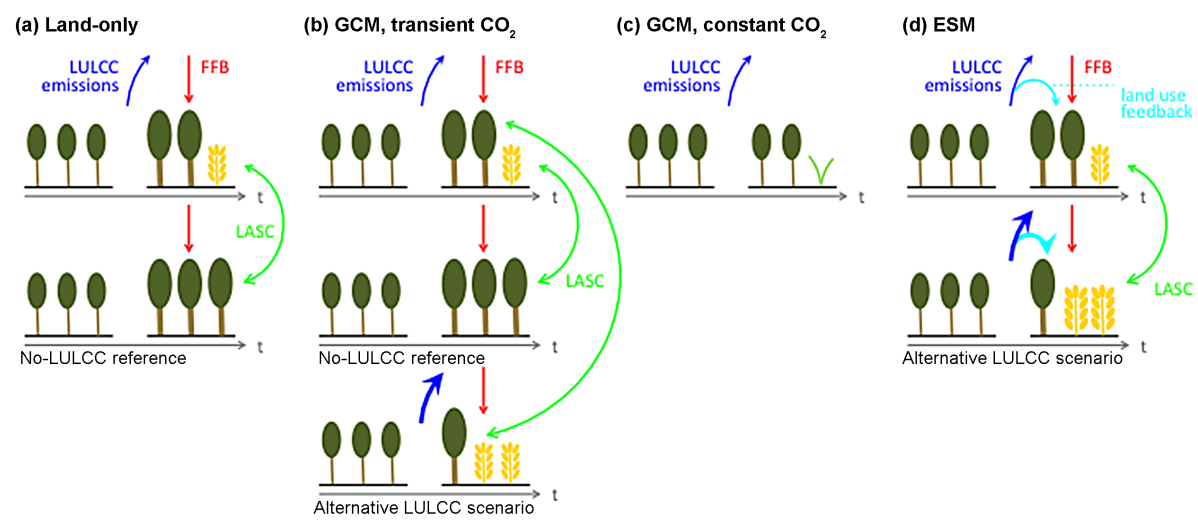

Figure 7. Illustration of the different setups used in the LUMIP experiments, using the example of forest replacement by cropland or grassland. The loss of additional sink capacity (LASC) is a factor when environmental conditions change transiently, which is the case when historical $\mathrm{CO}_{2}$ concentrations, which implicitly include increases in $\mathrm{CO}_{2}$ due to fossil-fuel burning (FFB) and LULCC, are prescribed from observations. Prognostic LULCC emissions are directly "seen" by the terrestrial vegetation (natural and anthropogenic) only in the ESM setup, where $\mathrm{CO}_{2}$ is interactive. In this case, a fraction of the LULCC emissions is taken up again by the vegetation ("land-use carbon feedback"). Note that only atmospheric $\mathrm{CO}_{2}$ is prescribed in (a-c), while other environmental conditions feed back with LULCC's biogeophysical effects.

of changes in albedo (Davin et al., 2014) and accumulated changes in soil moisture content (Wilhelm et al., 2015). Careful assessment will be necessary to validate the inferred relationships between LULCC and extremes, given partly contradicting results with respect to the effects of LULCC on climate extremes in models and observations (Lejeune et al., 2016; Teuling et al., 2010).

\section{Subgrid data reporting}

To address challenges of analyzing effects of LULCC on the physical and biogeochemical state of land and its interactions with the atmosphere (e.g., analyses proposed in Sects. 3.23.5), LUMIP is including a Tier 1 data request of sub-grid information for four sub-grid categories (i.e., tiles) to permit more detailed analysis of land-use-induced surface heterogeneity. The rationale for this request is that relevant and interesting sub-grid-scale data that represent the heterogeneity of the land surface are available from current land models but are not being used since sub-grid-scale quantities are typically averaged to grid cell means prior to delivery to the CMIP database. Several recent studies have demonstrated that valuable insight can be gained through analysis of subgrid information. For example, Fischer et al. (2012) used subgrid output to show that not only is heat stress higher in urban areas compared to rural areas in the present-day climate, but also that heat stress is projected to increase more rapidly in urban areas under climate change. Malyshev et al. (2015) found a much stronger signature of the climate impact of LULCC at the subgrid level (i.e., comparing simulated surface temperatures across different land-use tiles within a grid cell) than is apparent at the grid cell level. Subgrid analy- sis can also lead to improved understanding of how models operate. For example, Schultz et al. (2016) showed, through subgrid analysis of the Community Land Model, that the assumption that plants share a soil column and therefore compete for water and nutrients has the side-effect of an effective soil heat transfer between vegetation types that can alias into individual vegetation-type surface fluxes. Furthermore, reporting carbon pools and fluxes by tiles will enable assessment of land-use carbon fluxes not only with the standard method of looking at differences between land-use and no land-use experiments (e.g., as described in Sect. 3.2), but also within a single land-use experiment, utilizing bookkeeping approaches (Houghton et al., 2012) that allow a more direct comparison of observed and modeled carbon inventories.

\subsection{Types of land-use tiles}

Four land-use categories are requested for selected key variables: (1) primary and secondary land (including bare ground and vegetated wetlands), (2) cropland, (3) pastureland, and (4) urban (Table 4). Other sub-grid categories such as lakes, rivers, and glaciers are excluded from this request. The proposed set of land-use sub-grid reporting units closely corresponds to land-use categories to be used in the CMIP6 historical land-use reconstructions and future scenarios. Primary (i.e., natural vegetation never affected by LULCC activity) and secondary (i.e., natural vegetation that has previously been harvested or abandoned agricultural land with potential to regrow) land are combined because most land components of ESMs models do not yet distinguish between these two land types. 
Table 4. Land-use tile types and abbreviations.

\begin{tabular}{lll}
\hline Land-use tile type & Land-use tile abbreviation & Comment \\
\hline Primary and secondary land & psl & Forest, grasslands, and bare ground \\
Cropland & crp & \\
Pastureland & pst & Includes managed pastureland and rangeland \\
Urban settlement & urb & \\
\hline
\end{tabular}

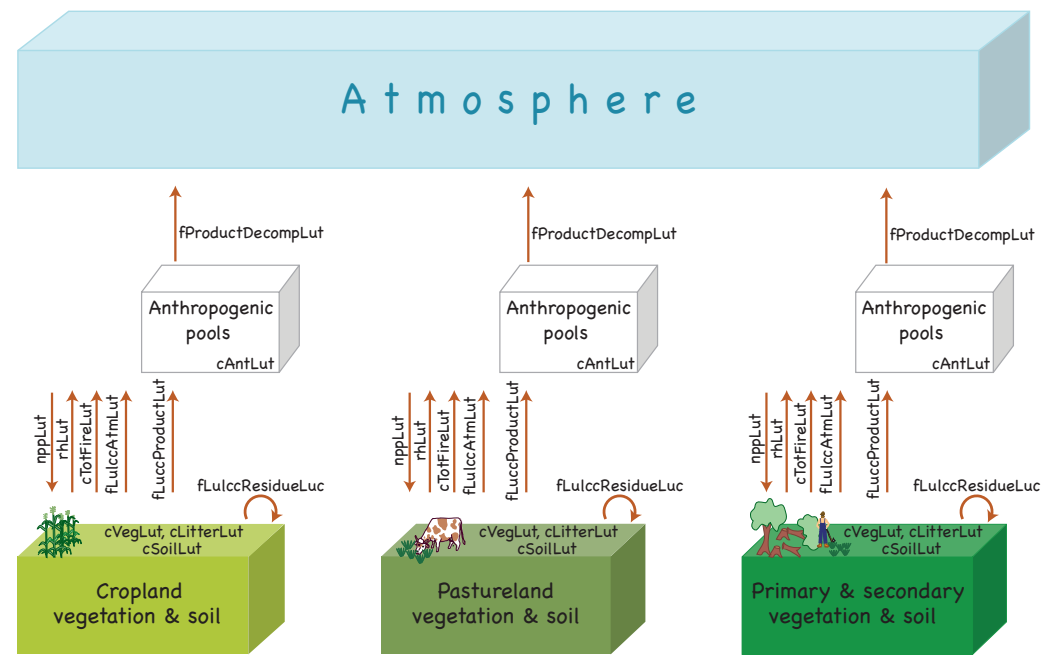

Figure 8. Exchanges and transfers affecting storage of biogeochemical constituents in land models under LULCC. Variable descriptions can be found in Table 5. Urban tile not shown, but if carbon fluxes are calculated on a particular model's urban tile, then these fluxes should be reported for the rban tile as well.

\subsection{Requested variables and rules for reporting}

Overall, there are five classes of variables that are requested. These variables describe (a) the subgrid structure and how it evolves through time, (b) biogeochemical fluxes, (c) biogeophysical variables, (d) LULCC fluxes and carbon transfers (Fig. 8), and (e) carbon stocks on land-use tiles. A list of requested land-use tile variables is shown in Table 5. However, this list is subject to change. Modelers should refer to the CMIP6 output request documents for the final variable list.

Subgrid tile variables should be submitted according to the following structure, using leaf area index (LAI) as an example: laiLut (lon, lat, time, landusetype4) - where the landusetype 4 dimension has an explicit order of psl, crp, pst, and urb, where "psl" is primary and secondary land, "crp" is cropland, "pst" is pastureland, and "urb" is urban.

It is recognized that different models have very different implementations of LULCC processes and may only be able to report a subset of variables/land-use tiles, but models are requested to report according to the following rules.

- The sum of the fractional areas for psl $+\mathrm{crp}+\mathrm{pst}+\mathrm{urb}$ may not add up to 1 for grid cells with lakes, glaciers, or other land sub-grid categories.
- If a model does not represent one of the requested landuse tiles, then it should report for these tiles with missing values.

- In cases where more than one land-use tile shares information, then duplicate information should be provided on each tile (e.g., if pastureland and cropland share the same soil, then duplicate information for soil variables should be provided on the pst and crp tiles).

- If a model does not represent one of the requested variables for any of the subgrid land-use tiles, then this variable should be omitted.

- Note that for variables where for a particular model the concept of a tiled quantity is not appropriate, that quantity should only be reported at the grid-cell level. An example is anthropogenic product pools (APPs). Many models do not track APPs at the subgrid tile level, instead aggregating all sources of APPs into a single gridcell-level APP variable. In this case, APP should only be reported at the grid-cell level as per the CMIP request. 
Table 5. List of requested variables on land-use tiles. Note that this list may be updated. Modelers should refer to the CMIP6 variable request lists for the final list.

\begin{tabular}{lll}
\hline Variable short name & Variable long name & Comments \\
\hline gppLut & \multicolumn{1}{c}{ Biogeochemical and ecological variables } \\
\hline raLut & Plant respiration on land-use tile & \\
\hline nppLut & Net primary productivity on land-use tile & \\
\hline cTotFireLut & $\begin{array}{l}\text { Total carbon loss from natural and managed fire } \\
\text { on a land-use tile, including deforestation fires }\end{array}$ & $\begin{array}{l}\text { Different from LMON, this flux should include all fires } \\
\text { occurring on the land-use tile, including natural, man- } \\
\text { made, and deforestation fires }\end{array}$ \\
\hline rhLut & Soil heterotrophic respiration on land-use tile & $\begin{array}{l}\text { Computed as npp minus heterotrophic respiration mi- } \\
\text { nus fire minus C leaching minus harvesting/clearing. } \\
\text { necbLut }\end{array}$ \\
tile & $\begin{array}{l}\text { Positive rate is into the land, negative rate is from the } \\
\text { land. Do not include fluxes from anthropogenic pools } \\
\text { to atmosphere }\end{array}$ \\
\hline
\end{tabular}

\begin{tabular}{|c|c|c|}
\hline nwdFracLut & $\begin{array}{l}\text { Fraction of land-use tile tile that is non-woody } \\
\text { vegetation (e.g., herbaceous crops) }\end{array}$ & \\
\hline \multicolumn{3}{|c|}{ Biogeophysical variables } \\
\hline tasLut & $\begin{array}{l}\text { Near-surface air temperature ( } 2 \mathrm{~m} \text { above dis- } \\
\text { placement height, i.e., } \mathrm{t} \text {-ref) on land-use tile }\end{array}$ & \\
\hline tslsiLut & Surface "skin" temperature on land-use tile & temperature at which longwave radiation emitted \\
\hline hussLut & Near-surface specific humidity on land-use tile & $\begin{array}{l}\text { Normally, the specific humidity should be reported at } \\
\text { the } 2 \mathrm{~m} \text { height. }\end{array}$ \\
\hline hflsLut & Latent heat flux on land-use tile & \\
\hline hfssLut & Sensible heat flux on land-use tile & \\
\hline rsusLut & Surface upwelling shortwave on land-use tile & \\
\hline rlusLut & Surface upwelling longwave on land-use tile & \\
\hline sweLut & Snow water equivalent on land-use tile & \\
\hline laiLut & Leaf area index on land-use tile & $\begin{array}{l}\text { Note that if tile does not model lai, for example, on the } \\
\text { urban tile, then should be reported as missing value }\end{array}$ \\
\hline mrsosLut & $\begin{array}{l}\text { Moisture in upper portion of soil column of } \\
\text { land-use tile }\end{array}$ & $\begin{array}{l}\text { the mass of water in all phases in a thin surface layer; } \\
\text { integrate over uppermost } 10 \mathrm{~cm}\end{array}$ \\
\hline mrroLut & Total runoff from land-use tile & $\begin{array}{l}\text { the total runoff (including "drainage" through the base } \\
\text { of the soil model) leaving the land-use tile portion of } \\
\text { the grid cell }\end{array}$ \\
\hline mrsoLut & Total soil moisture & \\
\hline irrLut & Irrigation flux & \\
\hline fahUrb & Anthropogenic heat flux & $\begin{array}{l}\text { Anthropogenic heat flux due to human activities such } \\
\text { as space heating and cooling or traffic or other energy } \\
\text { consumption }\end{array}$ \\
\hline
\end{tabular}


Table 5. Continued.

\begin{tabular}{|c|c|c|}
\hline Variable short name & Variable long name & Comments \\
\hline \multicolumn{3}{|c|}{ LULCC fluxes and carbon transfers } \\
\hline fProductDecompLut & $\begin{array}{l}\text { Flux from anthropogenic pools on land-use tile } \\
\text { into the atmosphere }\end{array}$ & $\begin{array}{l}\text { If a model has separate anthropogenic pools by land-use } \\
\text { tile }\end{array}$ \\
\hline fLulccProductLut & $\begin{array}{l}\text { carbon harvested due to land-use or land-cover } \\
\text { change process that enters anthropogenic prod- } \\
\text { uct pools on tile }\end{array}$ & $\begin{array}{l}\text { This annual mean flux refers to the transfer of car- } \\
\text { bon primarily through harvesting land use into anthro- } \\
\text { pogenic product pools, e.g., deforestation or wood har- } \\
\text { vesting from primary or secondary lands, food harvest- } \\
\text { ing on croplands, harvesting (grazing) by animals on } \\
\text { pastures. }\end{array}$ \\
\hline fLulccResidueLut & $\begin{array}{l}\text { Carbon transferred to soil or litter pools due to } \\
\text { land-use or land-cover change processes on tile }\end{array}$ & $\begin{array}{l}\text { This annual mean flux due refers to the transfer of car- } \\
\text { bon into soil or litter pools due to any land use or land- } \\
\text { cover change activities }\end{array}$ \\
\hline fLulccAtmLut & $\begin{array}{l}\text { Carbon transferred directly to atmosphere due } \\
\text { to any land-use or land-cover change activities } \\
\text { including deforestation or agricultural fire }\end{array}$ & $\begin{array}{l}\text { This annual mean flux refers to the transfer of carbon } \\
\text { directly to the atmosphere due to any land-use or land- } \\
\text { cover change activities. }\end{array}$ \\
\hline \multicolumn{3}{|c|}{ Carbon stock variables } \\
\hline cSoilLut & Carbon in soil pool on land-use tiles & end of year values (not annual mean) \\
\hline cVegLut & Carbon in vegetation on land-use tiles & end of year values (not annual mean) \\
\hline cLitterLut & $\begin{array}{l}\text { Carbon in above- and below-ground litter pools } \\
\text { on land-use tiles }\end{array}$ & end of year values (not annual mean) \\
\hline cAntLut & $\begin{array}{l}\text { Anthropogenic pools associated with land-use } \\
\text { tiles }\end{array}$ & $\begin{array}{l}\text { anthropogenic pools associated with land-use tiles into } \\
\text { which harvests are deposited before release into the } \\
\text { atmosphere PLUS any remaining anthropogenic pools } \\
\text { that may be associated with lands that were converted } \\
\text { into land-use tiles during the reported period. Does } \\
\text { NOT include residue that is deposited into soil or litter; } \\
\text { end of year values (not annual mean) }\end{array}$ \\
\hline
\end{tabular}

LULCC fraction changes

\begin{tabular}{lll}
\hline fracLut & Fraction of grid cell for each land-use tile & $\begin{array}{l}\text { end of year values (not annual mean); note that fraction } \\
\text { should be reported as fraction of land grid cell }\end{array}$ \\
\hline fracOutLut & $\begin{array}{l}\text { Annual gross fraction of the land-use tile that } \\
\text { was transferred in other land-use tiles }\end{array}$ & $\begin{array}{l}\text { cumulative annual fractional transitions out of each } \\
\text { land-use tile; for example, for primary and secondary } \\
\text { land-use tile, this would include all fractional transi- } \\
\text { tions from primary and secondary land into cropland, } \\
\text { pastureland, and urban for the year; note that fraction } \\
\text { should be reported as fraction of land grid cell }\end{array}$ \\
\hline fracInLut & $\begin{array}{ll}\text { Annual gross fraction that was transferred to } \\
\text { this tile from other land-use tiles }\end{array}$ & $\begin{array}{l}\text { cumulative annual fractional transitions into each land- } \\
\text { use tile; for example, for primary and secondary land- } \\
\text { use tile, this would include all fractional transitions } \\
\text { from cropland, pastureland, and urban into primary and } \\
\text { secondary land over the year; note that the fraction } \\
\text { should be reported as a fraction of a land-grid cell }\end{array}$ \\
\hline
\end{tabular}




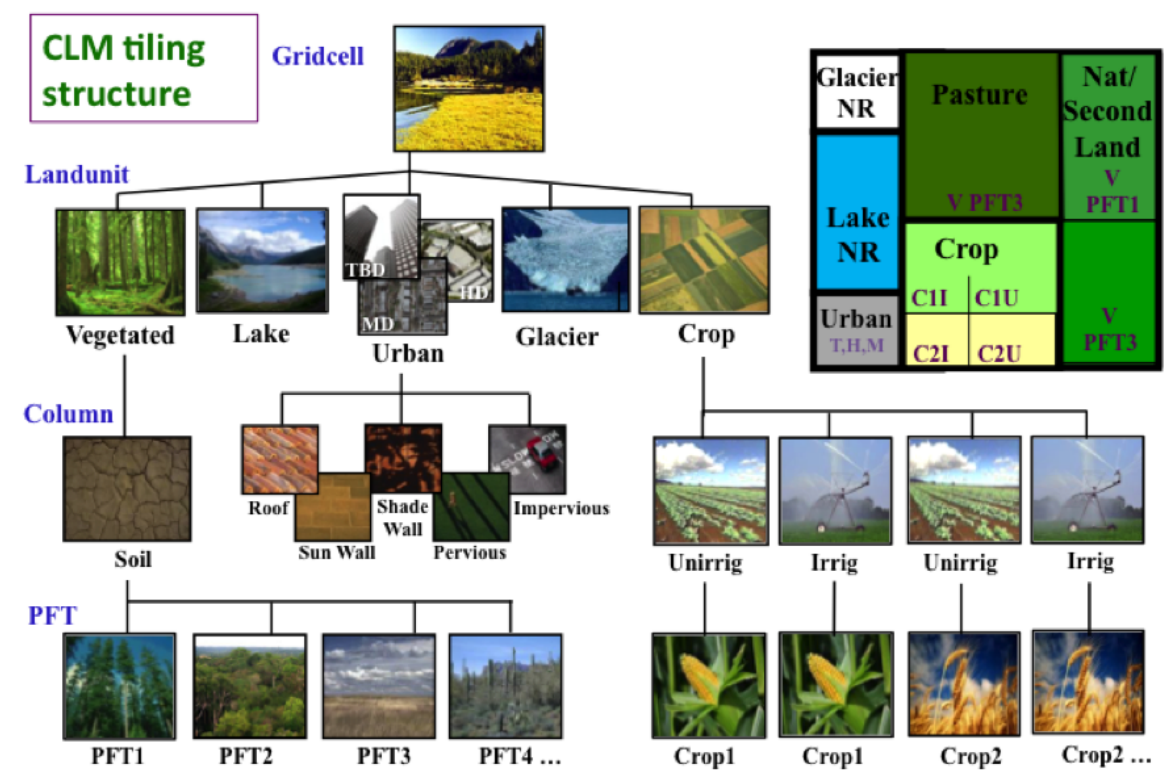

Figure 9. CLM tiling structure (Fig. 8, Oleson et al., 2013). Subgrid aggregation: PSL: vegetated land unit including all PFTs and bare soil; CRP: crop land unit including all crop types irrigated (I) and non-irrigated (U); PST: not explicitly represented in CLM, reported as a missing value; URB: weighted average of the Tall Building District, High Density, and Medium Density types in Urban land unit. Glacier and Lake are not reported.

\subsection{Land-use tile-reporting/aggregation for example models}

\subsubsection{Community Land Model (CLM) example}

CLM captures a variety of ecological and hydrological subgrid characteristics (Fig. 9, Lawrence et al., 2011; Oleson et al., 2013). Spatial land surface heterogeneity in CLM is represented as a nested subgrid hierarchy in which grid cells are composed of multiple land units, snow/soil columns, and PFTs. Each grid cell can have a different number of land units, each land unit can have a different number of columns, and each column can have multiple PFTs. The first subgrid level, the land unit, is intended to capture the broadest spatial patterns of subgrid heterogeneity. The CLM land units are glacier, lake, urban, vegetated, and crop. The land unit level can be used to further delineate these patterns. For example, the urban land unit is divided into density classes representing the tall building district, high density, and medium density urban areas. The second subgrid level, the column, is intended to capture potential variability in the soil and snow state variables within a single land unit. For example, the vegetated land unit could contain several columns with independently evolving vertical profiles of soil water and temperature. Similarly, the crop land unit is divided into multiple columns, two columns for each crop type (irrigated and nonirrigated). The central characteristic of the column subgrid level is that this is where the state variables for water and energy in the soil and snow are defined, as well as the fluxes of these components within the soil and snow. Regardless of the number and type of plant function types (PFTs) occupying space on the column, the column physics operates with a single set of upper boundary fluxes, as well as a single set of transpiration fluxes from multiple soil levels. These boundary fluxes are weighted averages over all PFTs. Currently, for glacier, lake, and vegetated land units, a single column is assigned to each land unit.

In order to meet requirements of the LUMIP sub-grid reporting request, the following aggregation would be required for CLM:

- Primary and secondary land (psl): vegetated land unit includes all primary and secondary land that includes all natural vegetation and bare soil.

- Crops (crp): crop land unit including all non-irrigated and irrigated crops

- Pastureland: not explicitly treated in CLM, reported as missing value

- Urban (urb): urban land unit including tall building, high density, and medium density areas

- Lakes and glaciers are not included in any of the LUMIP subgrid categories, and so are not reported.

\subsubsection{GFDL LM3 example}

GFDL CMIP5 land component LM3 (Shevliakova et al., 2009) resolves sub-grid land heterogeneity with respect to different land-use activities: each grid cell includes up to 15 


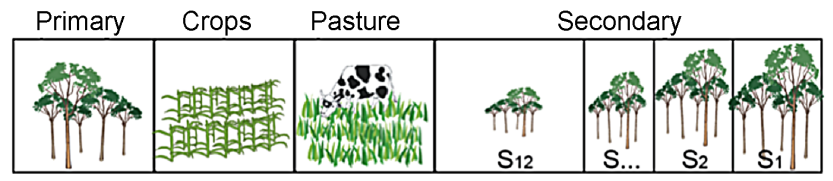

Figure 10. In the GFDL ESM2M and ESM2G CMIP5 simulations each grid cell has up to 15 land tiles, including lakes, glaciers, croplands, pasturelands, primary, and up to 10 secondary vegetation tiles. All GFDL models use gross transitions from the LULCC scenarios. The secondary vegetation tiles are generated by wood harvesting (primary to secondary and secondary to secondary transitions) as well as by agricultural abandonment (croplands to secondary and pastures to secondary transitions). Each land-use tile has its own $\mathrm{C}$ anthropogenic pool and separate above- and belowground $\mathrm{C}$ stores. For LUMIP, all variables on primary and secondary tiles will be aggregated and reported under the PSL tile. Urban is not represented and will be reported as missing values. Glaciers and lakes are not reported.

different tiles (including a bare soil tile) to represent differences in above- and below-ground hydrological and carbon states (Fig. 10). A grid cell could have one cropland tile, one pasture tile, one natural tile, and up to 12 secondary land tiles as well as lake and glacier tiles. Secondary tiles refer to lands that were harvested (i.e., prior primary or secondary) or abandoned agricultural lands, pastures, and croplands. The tiling structure of LM3 and ESM2 was designed to work with the CMIP5 LUH data set (Hurtt et al., 2011). Changes in the area and type of tiles occur annually based on gross transitions from the LUH data set. Similarly to the scenario design, secondary or agricultural lands are never allowed to return to primary lands. The physical and ecological states and properties of each of the tiles are different, and the physical and biogeochemical fluxes between land and the atmosphere are calculated separately for every tile. Each cropland, pasture, and secondary tile has three anthropogenic pools with three different residence times (1, 10, and 100 years). For LUMIP sub-grid tile reporting, all secondary and natural tiles will be aggregated into the primary and secondary tiles (PSL). For each requested land-use tile, the three different residencetime anthropogenic pools will be aggregated into one.

\section{Summary}

Here, we have outlined the rationale for the Land Use Model Intercomparison Project (LUMIP) of CMIP6. We provided detailed descriptions of the experimental design along with analysis plans and instructions for subgrid land-use tile data archiving. The efficient, yet comprehensive, experimental design, which has been developed through workshops and discussions among the land-use modeling and related communities over the past 2 years, includes idealized and realistic experiments in coupled and land-only model configurations. These experiments are designed to advance process-level un- derstanding of land-cover and land-use impacts on climate, to quantify model sensitivity to potential land-cover and landuse change, to assess the historic impact of land use, and to provide preliminary evaluation of the potential for targeted land use and management as a method to contribute to the mitigation of climate change. In addressing these topics, LUMIP will also study more detailed land-use science questions in more depth and sophistication than has been possible in a multi-model context to date. Analyses will focus on the separation and quantification of the effects on climate from LULCC relative to all forcings, separation of biogeochemical from biogeophysical effects of land use, the unique impacts of land-cover change vs. land-use change, modulation of land-use impact on climate by land-atmosphere coupling strength, the role of land-use change in climate extremes, and the extent to which impacts of enhanced $\mathrm{CO}_{2}$ concentrations on plant photosynthesis are modulated by past and future land use.

\section{Data availability}

As with all CMIP6-endorsed MIPs, the model output from the LUMIP simulations described in this paper will be distributed through the Earth System Grid Federation (ESGF). The natural and anthropogenic forcing data sets required for the simulations will be described in separate invited contributions to this Special Issue and made available through the ESGF with version control and digital object identifiers (DOIs) assigned. Links to all forcings data sets will be made available via the CMIP Panel website.

Author contributions. David M. Lawrence and George C. Hurtt are co-leads of LUMIP. David M. Lawrence wrote the document with contributions from all other authors.

Acknowledgements. We would like to thank Andy Pitman, Paul Dirmeyer, Alan DiVittorio, and Ron Stouffer for their thoughtful and constructive reviews that led to considerable improvements to the document. David M. Lawrence is supported by the US Department of Energy grants DE-FC03-97ER62402/A010 and DE-SC0012972 and US Department of Agriculture grant 2015-67003-23489. Julia Pongratz is supported by the German Research Foundation's Emmy Noether Program. Sonia I. Seneviratne acknowledges support from the European Research Council (ERC DROUGHT-HEAT project). Almut Arneth acknowledges support by the EC FP7 project LUC4C (grant no. 603542) and the Helmholtz Association through its ATMO programme. Nathalie de Noblet-Ducoudré acknowledges support by the EC FP7 project LUC4C (grant no. 603542) and by all participants to former LUCID exercises.

Edited by: J. Kala

Reviewed by: A. Di Vittorio, P. Dirmeyer, and A. Pitman 


\section{References}

Abramowitz, G.: Towards a public, standardized, diagnostic benchmarking system for land surface models, Geosci. Model Dev., 5, 819-827, doi:10.5194/gmd-5-819-2012, 2012.

Andrews, T., Betts, R., Booth, B., Jones, C. D., and Jones, G. S.: Effective radiative forcing from historical land use change, J. Climate, doi:10.1007/s00382-016-3280-7, online first, 2016.

Arora, V. and Boer, G.: Uncertainties in the 20th century carbon budget associated with land use change, Glob. Change Biol., 16, 3327-3348, 2010.

Badger, A. M. and Dirmeyer, P. A.: Climate response to Amazon forest replacement by heterogeneous crop cover, Hydrol. Earth Syst. Sci., 19, 4547-4557, doi:10.5194/hess-19-45472015, 2015.

Badger, A. M. and Dirmeyer, P. A.: Remote tropical and subtropical responses to Amazon deforestation, Clim. Dynam., 46, 3057-3066, 2016.

Bala, G., Caldeira, K., Wickett, M., Phillips, T., Lobell, D., Delire, C., and Mirin, A.: Combined climate and carbon-cycle effects of large-scale deforestation, P. Natl. Acad. Sci. USA, 104, 65506555, 2007.

Bathiany, S., Claussen, M., Brovkin, V., Raddatz, T., and Gayler, V.: Combined biogeophysical and biogeochemical effects of largescale forest cover changes in the MPI earth system model, Biogeosciences, 7, 1383-1399, doi:10.5194/bg-7-1383-2010, 2010.

Best, M., Abramowitz, G., Johnson, H., Pitman, A., Balsamo, G., Boone, A., Cuntz, M., Decharme, B., Dirmeyer, P., and Dong, J.: The plumbing of land surface models: benchmarking model performance, J. Hydrometeorol., 16, 1425-1442, 2015.

Boisier, J., de Noblet-Ducoudré, N., Pitman, A., Cruz, F., Delire, C., den Hurk, B., Molen, M., Müller, C., and Voldoire, A.: Attributing the impacts of land-cover changes in temperate regions on surface temperature and heat fluxes to specific causes: results from the first LUCID set of simulations, J. Geophys. Res., 117, D12116, doi:10.1029/2011JD017106, 2012.

Boisier, J. P., de Noblet-Ducoudré, N., and Ciais, P.: Inferring past land use-induced changes in surface albedo from satellite observations: a useful tool to evaluate model simulations, Biogeosciences, 10, 1501-1516, doi:10.5194/bg-10-1501-2013, 2013.

Boisier, J. P., de Noblet-Ducoudré, N., and Ciais, P.: Historical land-use-induced evapotranspiration changes estimated from present-day observations and reconstructed land-cover maps, Hydrol. Earth Syst. Sci., 18, 3571-3590, doi:10.5194/hess-183571-2014, 2014.

Bonan, G. B.: Forests and climate change: forcings, feedbacks, and the climate benefits of forests, Science, 320, 1444-1449, 2008.

Boucher, O., Myhre, G., and Myhre, A.: Direct human influence of irrigation on atmospheric water vapour and climate, Clim. Dynam., 22, 597-603, 2004.

Boysen, L. R., Brovkin, V., Arora, V. K., Cadule, P., de NobletDucoudré, N., Kato, E., Pongratz, J., and Gayler, V.: Global and regional effects of land-use change on climate in 21 st century simulations with interactive carbon cycle, Earth Syst. Dynam., 5, 309-319, doi:10.5194/esd-5-309-2014, 2014.

Brovkin, V., Boysen, L., Arora, V., Boisier, J., Cadule, P., Chini, L., Claussen, M., Friedlingstein, P., Gayler, V., and Van Den Hurk, B.: Effect of anthropogenic land-use and land-cover changes on climate and land carbon storage in CMIP5 projections for the twenty-first century, J. Climate, 26, 6859—6881, 2013.
Canadell, J. G. and Raupach, M. R.: Managing forests for climate change mitigation, Science, 320, 1456-1457, 2008.

Canadell, J. G., Le Quéré, C., Raupach, M. R., Field, C. B., Buitenhuis, E. T., Ciais, P., Conway, T. J., Gillett, N. P., Houghton, R., and Marland, G.: Contributions to accelerating atmospheric $\mathrm{CO}_{2}$ growth from economic activity, carbon intensity, and efficiency of natural sinks. P. Natl. Acad. Sci., 104, 18866-18870, 2007.

Chen, L. and Dirmeyer, P. A.: Adapting observationally based metrics of biogeophysical feedbacks from land cover/land use change to climate modeling, Environ. Res. Lett., 11, 034002, doi:10.1088/1748-9326/11/3/034002, 2016.

Christidis, N., Stott, P. A., Hegerl, G. C., and Betts, R. A.: The role of land use change in the recent warming of daily extreme temperatures, Geophys. Res. Lett., 40, 589-594, 2013.

Ciais, P., Sabine, C., Bala, G., Bopp, L., Brovkin, V., Canadell, J., Chhabra, A., DeFries, R., Galloway, J., and Heimann, M.: Carbon and other biogeochemical cycles, Climate Change 2013: The Physical Science Basis. Contribution of Working Group I to the Fifth Assessment Report of the Intergovernmental Panel on Climate Change, Cambridge University Press, 465-570, 2014.

Davies-Barnard, T., Valdes, P., Singarayer, J. S., Wiltshire, A., and Jones, C.: Quantifying the relative importance of land cover change from climate and land use in the representative concentration pathways, Global Biogeochem. Cy., 29, 842-853, 2015.

Davin, E., de Noblet-Ducoudré, N., and Friedlingstein, P.: Impact of land cover change on surface climate: Relevance of the radiative forcing concept, Geophys. Res. Lett., 34, L13702, doi:10.1029/2007GL029678, 2007.

Davin, E. L. and de Noblet-Ducoudré, N.: Climatic impact of global-scale deforestation: Radiative versus nonradiative processes, J. Climate, 23, 97-112, 2010.

Davin, E. L., Seneviratne, S. I., Ciais, P., Olioso, A., and Wang, T.: Preferential cooling of hot extremes from cropland albedo management. P. Natl. Acad. Sci. USA, 111, 9757-9761, 2014.

de Noblet-Ducoudré, N., Boisier, J.-P., Pitman, A., Bonan, G., Brovkin, V., Cruz, F., Delire, C., Gayler, V., Van den Hurk, B., and Lawrence, P.: Determining robust impacts of land-useinduced land cover changes on surface climate over North America and Eurasia: results from the first set of LUCID experiments, J. Climate, 25, 3261-3281, 2012.

Di Vittorio, A. V., Chini, L. P., Bond-Lamberty, B., Mao, J., Shi, X., Truesdale, J., Craig, A., Calvin, K., Jones, A., Collins, W. D., Edmonds, J., Hurtt, G. C., Thornton, P., and Thomson, A.: From land use to land cover: restoring the afforestation signal in a coupled integrated assessment-earth system model and the implications for CMIP5 RCP simulations, Biogeosciences, 11, 6435-6450, doi:10.5194/bg-11-6435-2014, 2014.

Dirmeyer, P. A., Wang, Z., Mbuh, M. J., and Norton, H. E.: Intensified land surface control on boundary layer growth in a changing climate, Geophys. Res. Lett., 41, 1290-1294, 2014.

Eyring, V., Bony, S., Meehl, G. A., Senior, C. A., Stevens, B., Stouffer, R. J., and Taylor, K. E.: Overview of the Coupled Model Intercomparison Project Phase 6 (CMIP6) experimental design and organization, Geosci. Model Dev., 9, 1937-1958, doi:10.5194/gmd-9-1937-2016, 2016.

Fischer, E., Oleson, K., and Lawrence, D.: Contrasting urban and rural heat stress responses to climate change, Geophys. Res. Lett., 39, L03705, doi:10.1029/2011GL050576, 2012. 
Foley, J. A., Ramankutty, N., Brauman, K. A., Cassidy, E. S., Gerber, J. S., Johnston, M., Mueller, N. D., O'Connell, C., Ray, D. K., and West, P. C.: Solutions for a cultivated planet, Nature, 478, 337-342, 2011.

Fujimori, S., Hasegawa, T., Masui, T., Takahashi, K., Herran, D. S., Dai, H., Hijoka, Y., and Kainuma, M.: SSP3: AIM Implementation of Shared Socioeconomic Pathways, Global Environ. Chang., doi:10.1016/j.gloenvcha.2016.06.009, online first, 2016.

Gerber, S., Hedin, L. O., Keel, S. G., Pacala, S. W., and Shevliakova, E.: Land use change and nitrogen feedbacks constrain the trajectory of the land carbon sink, Geophys. Res. Lett., 40, 5218-5222, 2013.

Gillett, N. P., Shiogama, H., Funke, B., Hegerl, G., Knutti, R., Matthes, K., Santer, B. D., Stone, D., and Tebaldi, C.: Detection and Attribution Model Intercomparison Project (DAMIP), Geosci. Model Dev. Discuss., doi:10.5194/gmd-2016-74, in review, 2016.

Gitz, V. and Ciais, P.: Amplifying effects of land-use change on future atmospheric $\mathrm{CO}_{2}$ levels, Global Biogeochem. Cy., 17, 1024, doi:10.1029/2002GB001963, 2003.

Gray, J. M., Frolking, S., Kort, E. A., Ray, D. K., Kucharik, C. J., Ramankutty, N., and Friedl, M. A.: Direct human influence on atmospheric $\mathrm{CO}_{2}$ seasonality from increased cropland productivity, Nature, 515, 398-401, 2014.

Greve, P., Orlowsky, B., Mueller, B., Sheffield, J., Reichstein, M., and Seneviratne, S. I.: Global assessment of trends in wetting and drying over land, Nat. Geosci., 7, 716-721, 2014.

Guo, Z., Dirmeyer, P. A., Koster, R. D., Sud, Y., Bonan, G., Oleson, K. W., Chan, E., Verseghy, D., Cox, P., and Gordon, C.: GLACE: the global land-atmosphere coupling experiment. Part II: analysis, J. Hydrometeorol., 7, 611-625, 2006.

Hansen, M. C., Potapov, P. V., Moore, R., Hancher, M., Turubanova, S., Tyukavina, A., Thau, D., Stehman, S., Goetz, S., and Loveland, T.: High-resolution global maps of 21st-century forest cover change, Science, 342, 850-853, 2013.

Hansis, E., Davis, S. J., and Pongratz, J.: Relevance of methodological choices for accounting of land use change carbon fluxes, Global Biogeochem. Cy., 29, 1230-1246, 2015.

Hirsch, A. L., Pitman, A., Kala, J., Lorenz, R., and Donat, M.: Modulation of Land-Use Change Impacts on Temperature Extremes via Land-Atmosphere Coupling over Australia, Earth Interact., 19, 1-24, 2015.

Houghton, R. A.: Revised estimates of the annual net flux of carbon to the atmosphere from changes in land use and land management 1850-2000, Tellus B, 55, 378-390, 2003.

Houghton, R. A., House, J. I., Pongratz, J., van der Werf, G. R., DeFries, R. S., Hansen, M. C., Le Quéré, C., and Ramankutty, N.: Carbon emissions from land use and land-cover change, Biogeosciences, 9, 5125-5142, doi:10.5194/bg-9-5125-2012, 2012.

Hurtt, G., Chini, L. P., Frolking, S., Betts, R., Feddema, J., Fischer, G., Fisk, J., Hibbard, K., Houghton, R., and Janetos, A.: Harmonization of land-use scenarios for the period 1500-2100: 600 years of global gridded annual land-use transitions, wood harvest, and resulting secondary lands, Climatic Change, 109, 117-161, 2011.

Jensen, M., Rangeley, W., and Dieleman, P.: Irrigation trends in world agriculture, Agronomy, 31-67, 1990.
Jones, A. D., Collins, W. D., and Torn, M. S.: On the additivity of radiative forcing between land use change and greenhouse gases, Geophys. Res. Lett., 40, 4036-4041, 2013 a.

Jones, A. D., Collins, W. D., Edmonds, J., Torn, M. S., Janetos, A., Calvin, K. V., Thomson, A., Chini, L. P., Mao, J., and Shi, $\mathrm{X}$.: Greenhouse gas policy influences climate via direct effects of land-use change, J. Climate, 26, 3657-3670, 2013b.

Jones, C. D., Arora, V., Friedlingstein, P., Bopp, L., Brovkin, V., Dunne, J., Graven, H., Hoffman, F., Ilyina, T., John, J. G., Jung, M., Kawamiya, M., Koven, C., Pongratz, J., Raddatz, T., Randerson, J. T., and Zaehle, S.: C4MIP - The Coupled Climate-Carbon Cycle Model Intercomparison Project: experimental protocol for CMIP6, Geosci. Model Dev., 9, 2853-2880, doi:10.5194/gmd-92853-2016, 2016.

Klein Goldewijk, K., Beusen, A., Van Drecht, G., and De Vos, M.: The HYDE 3.1 spatially explicit database of human-induced global land-use change over the past 12,000 years, Global Ecol. Biogeogr., 20, 73-86, 2011.

Koster, R. D., Dirmeyer, P. A., Guo, Z., Bonan, G., Chan, E., Cox, P., Gordon, C., Kanae, S., Kowalczyk, E., and Lawrence, D.: Regions of strong coupling between soil moisture and precipitation, Science, 305, 1138-1140, 2004.

Kriegler, E., Bauer, N., Popp, A., Humpenöder, F., Leimbach, M., Strefler, J., Baumstark, L., Bodirsky, B.L., Hilaire, J., Klein, D., and Mouratiadou, I.: Fossil-fueled development (SSP5): an energy and resource intensive scenario for the 21st century, Global Environ. Chang., doi:10.1016/j.gloenvcha.2016.05.015, online first, 2016.

Kumar, S., Dirmeyer, P. A., Merwade, V., DelSole, T., Adams, J. M., and Niyogi, D.: Land use/cover change impacts in CMIP5 climate simulations: A new methodology and 21 st century challenges, J. Geophys. Res., 118, 6337-6353, 2013.

Kumar, S. V., Peters-Lidard, C. D., Santanello, J., Harrison, K., Liu, Y., and Shaw, M.: Land surface Verification Toolkit (LVT) - a generalized framework for land surface model evaluation, Geosci. Model Dev., 5, 869-886, doi:10.5194/gmd-5-869-2012, 2012.

Lambin, E. F., Geist, H., and Rindfuss, R. R.: Introduction: local processes with global impacts, Land-use and land-cover change, Springer-Verlag, Berlin, 1-8, 2006.

Lawrence, D. M., Oleson, K. W., Flanner, M. G., Thornton, P. E., Swenson, S. C., Lawrence, P. J., Zeng, X., Yang, Z. L., Levis, S., and Sakaguchi, K.: Parameterization improvements and functional and structural advances in version 4 of the Community Land Model, J. Adv. Model. Earth Syst., 3, M03001, doi:10.1029/2011MS000045, 2011.

Lawrence, P. J., Feddema, J. J., Bonan, G. B., Meehl, G. A., O’Neill, B. C., Oleson, K. W., Levis, S., Lawrence, D. M., Kluzek, E., Lindsay, K., and Thornton, P. E.: Simulating the Biogeochemical and Biogeophysical Impacts of Transient Land Cover Change and Wood Harvest in the Community Climate System Model (CCSM4) from 1850 to 2100, J. Climate, 25, 3071-3095, doi:10.1175/jcli-d-11-00256.1, 2012.

Lawrence, D. M., Hurtt, G. C., Arneth, A., Brovkin, V., Calvin, K. V., Jones, A. D., Jones, C. D., Lawrence, P. J., de NobletDucoudre, N., Pongratz, J., Seneviratne, S. I., and Shevliakova, E.: LUMIP Project, available at: https://cmip.ucar.edu/lumip, last access: 31 August 2016. 
Lee, X., Goulden, M. L., Hollinger, D. Y., Barr, A., Black, T. A., Bohrer, G., Bracho, R., Drake, B., Goldstein, A., and Gu, L.: Observed increase in local cooling effect of deforestation at higher latitudes, Nature, 479, 384-387, 2011.

Lejeune, Q., Seneviratne, S. I., and Davin, E. L.: Comparative assessment of mid-latitude land-cover change effects on temperature in historical LUCID and CMIP5 simulations, J. Climate, submitted, 2016.

Levis, S., Bonan, G. B., Kluzek, E., Thornton, P. E., Jones, A., Sacks, W. J., and Kucharik, C. J.: Interactive crop management in the Community Earth System Model (CESM1): Seasonal influences on land-atmosphere fluxes, J. Climate, 25, 4839-4859, 2012.

Li, Y., Zhao, M., Motesharrei, S., Mu, Q., Kalnay, E., and Li, S.: Local cooling and warming effects of forests based on satellite observations, Nat. Commun., 6, 6603, doi:10.1038/ncomms7603, 2015.

Li, Y., De Noblet-Ducoudré, N., Davin, E. L., Motesharrei, S., Zeng, N., Li, S., and Kalnay, E.: The role of spatial scale and background climate in the latitudinal temperature response to deforestation, Earth Syst. Dynam., 7, 167-181, doi:10.5194/esd-7167-2016, 2016.

Lobell, D. B., Bonfils, C., and Faurès, J.-M.: The role of irrigation expansion in past and future temperature trends, Earth Interact., 12, 1-11, 2008a.

Lobell, D. B., Bonfils, C. J., Kueppers, L. M., and Snyder, M. A.: Irrigation cooling effect on temperature and heat index extremes, Geophys. Res. Lett., 35, L09705, doi:10.1029/2008GL034145, 2008b.

Lorenz, R. and Pitman, A. J.: Effect of land-atmosphere coupling strength on impacts from Amazonian deforestation, Geophys. Res. Lett., 41, 5987-5995, 2014.

Lorenz, R., Pitman, A., and Sisson, S.: Does Amazonian deforestation cause global effects; can we be sure?, J. Geophys. Res.Atmos., 121, 5567-5584, doi:10.1002/2015JD024357, 2016.

Luo, Y. Q., Randerson, J. T., Abramowitz, G., Bacour, C., Blyth, E., Carvalhais, N., Ciais, P., Dalmonech, D., Fisher, J. B., Fisher, R., Friedlingstein, P., Hibbard, K., Hoffman, F., Huntzinger, D., Jones, C. D., Koven, C., Lawrence, D., Li, D. J., Mahecha, M., Niu, S. L., Norby, R., Piao, S. L., Qi, X., Peylin, P., Prentice, I. C., Riley, W., Reichstein, M., Schwalm, C., Wang, Y. P., Xia, J. Y., Zaehle, S., and Zhou, X. H.: A framework for benchmarking land models, Biogeosciences, 9, 3857-3874, doi:10.5194/bg-93857-2012, 2012.

Luyssaert, S., Ciais, P., Piao, S., Schulze, E. D., Jung, M., Zaehle, S., Schelhaas, M., Reichstein, M., Churkina, G., and Papale, D.: The European carbon balance. Part 3: forests, Glob. Change Biol., 16, 1429-1450, 2010.

Luyssaert, S., Jammet, M., Stoy, P. C., Estel, S., Pongratz, J., Ceschia, E., Churkina, G., Don, A., Erb, K., and Ferlicoq, M.: Land management and land-cover change have impacts of similar magnitude on surface temperature, Nat. Clim. Change, 4, 389-393, 2014.

Mahowald, N., Lindsey, K., Munoz, E., Doney, S. C., Lawrence, P. J., Schlunegger, S., Ward, D., Lawrence, D. M., and Hoffman, F.: Interactions between land use change and carbon cycle feedbacks, Global Biogeochem. Cy., in review, 2016.

Malyshev, S., Shevliakova, E., Stouffer, R. J., and Pacala, S. W.: Contrasting Local versus Regional Effects of Land-Use-Change-
Induced Heterogeneity on Historical Climate: Analysis with the GFDL Earth System Model, J. Climate, 28, 5448-5469, 2015.

Marland, G., Pielke Sr., R. A., Apps, M., Avissar, R., Betts, R. A., Davis, K. J., Frumhoff, P. C., Jackson, S. T., Joyce, L. A., and Kauppi, P.: The climatic impacts of land surface change and carbon management, and the implications for climate-change mitigation policy, Clim. Policy, 3, 149-157, 2003.

Monfreda, C., Ramankutty, N., and Foley, J. A.: Farming the planet: 2. Geographic distribution of crop areas, yields, physiological types, and net primary production in the year 2000, Global Biogeochem. Cy., 22, GB1022, doi:10.1029/2007GB002947, 2008.

Mueller, N. D., Butler, E. E., McKinnon, K. A., Rhines, A., Tingley, M., Holbrook, N. M., and Huybers, P.: Cooling of US Midwest summer temperature extremes from cropland intensification, Nat. Clim. Change, 6, 317-322, doi:10.1038/nclimate2825, 2016.

Myhre, G., Shindell, D., Bréon, F.-M., Collins, W., Fuglestvedt, J., Huang, J., Koch, D., Lamarque, J.-F., Lee, D., Mendoza, B., Nakajima, T., Robock, A., Stephens, G., Takemura, T., and Zhang, H.: Anthropogenic and Natural Radiative Forcing, Climate Change 2013: The Physical Science Basis. Contribution of Working Group I to the Fifth Assessment Report of the Intergovernmental Panel on Climate Change, edited by: Stocker, T. F., Qin, D., Plattner, G.-K., Tignor, M., Allen, S. K., Boschung, J., Nauels, A., Xia, Y., Bex, V., and Midgley, P.M., Cambridge University Press, Cambridge, United Kingdom and New York, NY, USA, 2013.

O’Neill, B. C., Tebaldi, C., van Vuuren, D., Eyring, V., Friedlingstein, P., Hurtt, G., Knutti, R., Kriegler, E., Lamarque, J.-F., Lowe, J., Meehl, J., Moss, R., Riahi, K., and Sanderson, B. M.: The Scenario Model Intercomparison Project (ScenarioMIP) for CMIP6, Geosci. Model Dev. Discuss., doi:10.5194/gmd-201684, in review, 2016.

Oleson, K. W., Lawrence, D. M., Bonan, G. B., Drewniak, B., Huang, M., Koven, C. D., Levis, S., Li, F., Riley, W. J., Subin, Z. M., Swenson, S. C., and Thornton, P. E.: Technical Description of version 4.5 of the Community Land Model (CLM), Ncar Technical Note NCAR/TN-503+STR, National Center for Atmospheric Research, Boulder, CO, 422 pp. doi:10.5065/D6RR1W7M, 2013.

Pielke, R. A., Pitman, A., Niyogi, D., Mahmood, R., McAlpine, C., Hossain, F., Goldewijk, K. K., Nair, U., Betts, R., and Fall, S.: Land use/land cover changes and climate: modeling analysis and observational evidence. Wiley Interdisciplinary Reviews: Climate Change, 2, 828-850, 2011.

Pincus, R., Forster, P. M., and Stevens, B.: The Radiative Forcing Model Intercomparison Project (RFMIP): Experimental Protocol for CMIP6, Geosci. Model Dev. Discuss., doi:10.5194/gmd2016-88, in review, 2016.

Pitman, A., de Noblet-Ducoudré, N., Cruz, F., Davin, E., Bonan, G., Brovkin, V., Claussen, M., Delire, C., Ganzeveld, L., and Gayler, V.: Uncertainties in climate responses to past land cover change: First results from the LUCID intercomparison study, Geophys Res. Lett., 36, L14814, doi:10.1029/2009GL039076, 2009.

Pongratz, J. and Caldeira, K.: Attribution of atmospheric $\mathrm{CO}_{2}$ and temperature increases to regions: importance of preindustrial land use change, Environ. Res. Lett., 7, 034001, doi:10.1088/1748-9326/7/3/034001, 2012. 
Pongratz, J., Reick, C., Raddatz, T., and Claussen, M.: A reconstruction of global agricultural areas and land cover for the last millennium, Global Biogeochem. Cy., 22, GB3018, doi:10.1029/2007GB003153, 2008.

Pongratz, J., Reick, C., Raddatz, T., and Claussen, M.: Effects of anthropogenic land cover change on the carbon cycle of the last millennium, Global Biogeochem. Cy., 23, GB4001, doi:10.1029/2009GB003488, 2009.

Pongratz, J., Reick, C. H., Houghton, R. A., and House, J. I.: Terminology as a key uncertainty in net land use and land cover change carbon flux estimates, Earth Syst. Dynam., 5, 177-195, doi:10.5194/esd-5-177-2014, 2014.

Pugh, T., Arneth, A., Olin, S., Ahlström, A., Bayer, A., Goldewijk, K. K., Lindeskog, M., and Schurgers, G.: Simulated carbon emissions from land-use change are substantially enhanced by accounting for agricultural management, Environ. Res. Lett., 10, 124008, doi:10.1088/1748-9326/10/12/124008, 2015.

Randerson, J. T., Hoffman, F. M., Thornton, P. E., Mahowald, N. M., Lindsay, K., Lee, Y. H., Nevison, C. D., Doney, S. C., Bonan, G., and Stöckli, R.: Systematic assessment of terrestrial biogeochemistry in coupled climate-carbon models, Glob. Change Biol., 15, 2462-2484, 2009.

Reid, W. V., Chen, D., Goldfarb, L., Hackmann, H., Lee, Y., Mokhele, K., Ostrom, E., Raivio, K., Rockström, J., and Schellnhuber, H. J.: Earth system science for global sustainability: grand challenges, Science, 330, 916-917, 2010.

Riahi, K., van Vuuren, D. P., Kriegler, E., Edmonds, J., O’Neill, B., Fujimori, S., Bauer, N., Calvin, K., Dellink, R., Fricko, O., Lutz, W., Popp, A., Cuaresma, J. C., Samir, K. C., Leimbach, M., Jiang, L., Kram, T., Rao, S., Emmerling, J., Ebi, K., Hasegawa, T., Havlik, P., Humpenöder, F., Da Silva, L. A., Smith, S., Stehfest, E., Bosetti, V., Eom, J., Gernaat, D., Masui, T., Rogelj, J., Strefler, J., Drouet, L., Krey, V., Luderer, G., Harmsen, M., Takahashi, K., Baumstark, L., Doelman, J., Kainuma, M., Klimont, Z., Marangoni, G., Lotze-Campen, H., Obersteiner, M., Tabeau, A., and Tavon, M.: The Shared Socioeconomic Pathways: An Overview, Global Environ. Chang., in press, 2016.

Sacks, W. J., Cook, B. I., Buenning, N., Levis, S., and Helkowski, J. H.: Effects of global irrigation on the near-surface climate, Clim. Dynam., 33, 159-175, 2009.

Schneck, R., Reick, C. H., and Raddatz, T.: Land contribution to natural $\mathrm{CO}_{2}$ variability on time scales of centuries, J. Adv. Model. Earth Syst., 5, 354-365, 2013.

Schultz, N., Lee, X., Lawrence, P., Lawrence, D., and Zhao, L.: Assessing the use of sub-grid land model output to study impacts of land cover change, J. Geophys. Res., 121, 6133-6147, doi:10.1002/2016JD025094, 2016.

Seneviratne, S. I., Lüthi, D., Litschi, M., and Schär, C.: Landatmosphere coupling and climate change in Europe, Nature, 443, 205-209, 2006.

Seneviratne, S. I., Corti, T., Davin, E. L., Hirschi, M., Jaeger, E. B., Lehner, I., Orlowsky, B., and Teuling, A. J.: Investigating soil moisture-climate interactions in a changing climate: A review, Earth-Sci. Rev., 99, 125-161, 2010.

Seneviratne, S. I., Wilhelm, M., Stanelle, T., Hurk, B., Hagemann, S., Berg, A., Cheruy, F., Higgins, M. E., Meier, A., and Brovkin, V.: Impact of soil moisture-climate feedbacks on CMIP5 projections: First results from the GLACE-CMIP5 experiment, Geophys. Res. Lett., 40, 5212-5217, 2013.
Sentman, L. T., Shevliakova, E., Stouffer, R. J., and Malyshev, S.: Time scales of terrestrial carbon response related to land-use application: Implications for initializing an Earth system model, Earth Interact., 15, 1-16, 2011.

Shevliakova, E., Pacala, S. W., Malyshev, S., Hurtt, G. C., Milly, P., Caspersen, J. P., Sentman, L. T., Fisk, J. P., Wirth, C., and Crevoisier, C.: Carbon cycling under 300 years of land use change: Importance of the secondary vegetation sink, Global Biogeochem. Cy., 23, GB2022, doi:10.1029/2007GB003176, 2009.

Shevliakova, E., Stouffer, R. J., Malyshev, S., Krasting, J. P., Hurtt, G. C., and Pacala, S. W.: Historical warming reduced due to enhanced land carbon uptake, P. Natl. Acad. Sci. USA, 110, 1673016735, 2013.

Smith, P., Davis, S. J., Creutzig, F., Fuss, S., Minx, J., Gabrielle, B., Kato, E., Jackson, R. B., Cowie, A., and Kriegler, E.: Biophysical and economic limits to negative $\mathrm{CO}_{2}$ emissions, Nat. Clim. Change, 6, 42-50, 2016.

Snyder, P. K.: The influence of tropical deforestation on the Northern Hemisphere climate by atmospheric teleconnections, Earth Interact., 14, 1-34, 2010.

Stocker, B. D. and Joos, F.: Quantifying differences in land use emission estimates implied by definition discrepancies, Earth Syst. Dynam., 6, 731-744, doi:10.5194/esd-6-731-2015, 2015.

Stocker, B. D., Feissli, F., Strassmann, K. M., Spahni, R., and Joos, F.: Past and future carbon fluxes from land use change, shifting cultivation and wood harvest, Tellus B, 66, 23188, doi:10.3402/tellusb.v66.23188, 2014.

Swann, A. L., Fung, I. Y., and Chiang, J. C.: Mid-latitude afforestation shifts general circulation and tropical precipitation, P. Natl Acad. Sci. USA, 109, 712-716, 2012.

Teuling, A. J., Seneviratne, S. I., Stöckli, R., Reichstein, M., Moors, E., Ciais, P., Luyssaert, S., van den Hurk, B., Ammann, C., and Bernhofer, C.: Contrasting response of European forest and grassland energy exchange to heatwaves, Nat. Geosci., 3, 722727, 2010.

van den Hurk, B., Kim, H., Krinner, G., Seneviratne, S. I., Derksen, C., Oki, T., Douville, H., Colin, J., Ducharne, A., Cheruy, F., Viovy, N., Puma, M. J., Wada, Y., Li, W., Jia, B., Alessandri, A., Lawrence, D. M., Weedon, G. P., Ellis, R., Hagemann, S., Mao, J., Flanner, M. G., Zampieri, M., Materia, S., Law, R. M., and Sheffield, J.: LS3MIP (v1.0) contribution to CMIP6: the Land Surface, Snow and Soil moisture Model Intercomparison Project - aims, setup and expected outcome, Geosci. Model Dev., 9, 2809-2832, doi:10.5194/gmd-9-2809-2016, 2016.

Van Vuuren, D. P., Kriegler, E., O’Neill, B. C., Ebi, K. L., Riahi, K., Carter, T. R., Edmonds, J., Hallegatte, S., Kram, T., and Mathur, R.: A new scenario framework for climate change research: scenario matrix architecture, Climatic Change, 122, 373-386, 2014

Van Vuuren, D. P., Stehfest, E., Gernaat, D., Doelman, J., van Berg, M., Harmsen, M., de Boer, H.-S., Bouwman, L., Daiogolou, V., Edelenbosch, O., Girod, B., Kram, T., Lassaletta, L., Lucas, P., van Meijil, H., Muller, C., Rvan Ruijven, B., and Tabeau, A.: Energy, land-use and greenhouse gas emissions trajectories under a green growth paradigm, Global Environ. Chang., doi:10.1016/j.gloenvcha.2016.05.008, online first, 2016.

Ward, D. S., Mahowald, N. M., and Kloster, S.: Potential climate forcing of land use and land cover change, Atmos. Chem. Phys., 14, 12701-12724, doi:10.5194/acp-14-12701-2014, 2014. 
Wei, J., Dirmeyer, P. A., Wisser, D., Bosilovich, M. G., and Mocko, D. M.: Where does the irrigation water go? An estimate of the contribution of irrigation to precipitation using MERRA, J. Hydrometeorol., 14, 275-289, 2013.

Wilhelm, M., Davin, E. L., and Seneviratne, S. I.: Climate engineering of vegetated land for hot extremes mitigation: An Earth system model sensitivity study, J. Geophys. Res., 120, 2612-2623, 2015.

Wilkenskjeld, S., Kloster, S., Pongratz, J., Raddatz, T., and Reick, C. H.: Comparing the influence of net and gross anthropogenic land-use and land-cover changes on the carbon cycle in the MPIESM, Biogeosciences, 11, 4817-4828, doi:10.5194/bg-11-48172014, 2014.
Williams, C. A., Reichstein, M., Buchmann, N., Baldocchi, D., Beer, C., Schwalm, C., Wohlfahrt, G., Hasler, N., Bernhofer, C., and Foken, T.: Climate and vegetation controls on the surface water balance: Synthesis of evapotranspiration measured across a global network of flux towers, Water Resour. Res., 48, W06523, doi:10.1029/2011WR011586, 2012.

Zeng, N., Zhao, F., Collatz, G. J., Kalnay, E., Salawitch, R. J., West, T. O., and Guanter, L.: Agricultural Green Revolution as a driver of increasing atmospheric $\mathrm{CO}_{2}$ seasonal amplitude, Nature, 515, 394-397, 2014.

Zhang, X., Davidson, E. A., Mauzerall, D. L., Searchinger, T. D., Dumas, P., and Shen, Y.: Managing nitrogen for sustainable development, Nature, 528, 51-59, 2015. 